Biogeosciences Discuss., https://doi.org/10.5194/bg-2018-433

Manuscript under review for journal Biogeosciences

Discussion started: 19 October 2018

(c) Author(s) 2018. CC BY 4.0 License.

\title{
2 The role of light as vital effect on coral skeleton oxygen
}

\section{3 isotopic ratio}

4

5 Anne Juillet-Leclerc

6 LSCE Domaine du CNRS, 91198 Gif-sur-Yvette, France

$7 \quad$ Correspondence to: Anne.Juillet-Leclerc@1sce.ipsl.fr

\section{Abstract}

Light, an environmental parameter playing a crucial role in coral aragonite growth and $\delta^{18} \mathrm{O}$ formulation, is always neglected in the geochemical literature. However, by revisiting already published studies, we demonstrated that light might be considered as a vital effect affecting coral aragonite oxygen isotopic ratios.

Re-examining data series included in a publication by Weber and Woodhead (1972), we stressed that annual $\delta^{18} \mathrm{O}$-annual temperature calibrations of all considered coral genera may be compared because their assessment assumes homogenous light levels. Temperature prevails on $\delta^{18} \mathrm{O}$ because it influences $\delta^{18} \mathrm{O}$ in two ways: firstly it acts as is thermodynamically predicted implying a $\delta^{18} \mathrm{O}$ decrease; and secondly it induces an enhancement of photosynthesis causing $\delta^{18} \mathrm{O}$ increase. When the highest annual temperature occurs simultaneously with the highest annual irradiation, the annual $\delta^{18} \mathrm{O}$ amplitude is shortened. The annual $\delta^{18} \mathrm{O}$-annual temperature calibration is also explained by the relative distribution of microstructures, centres of calcification or COC and fibers, according to morphology, and in turn taxonomy. We also investigated monthly $\delta^{18} \mathrm{O}$-monthly temperature calibrations of Porites grown at the same sites as by Stephans and Quinn (2002), Linsley et al. (1999, 2000) and Maier et al. (2004). Multiple evidence showed that temperature is the prevailing environment forcing on $\delta^{18} \mathrm{O}$ and that the mixture of temperature and light also determines the relative distribution of microstructures, 
Biogeosciences Discuss., https://doi.org/10.5194/bg-2018-433

Manuscript under review for journal Biogeosciences

Discussion started: 19 October 2018

(c) Author(s) 2018. CC BY 4.0 License.

27 explaining the relationships between Porites calibration constants. By examining monthly and annual

$28 \delta^{18} \mathrm{O}-$ monthly and annual temperature calibrations, we revealed that monthly calibration results from

29 the superimposition of seasonal and annual variability over time. Seasonal $\delta^{18} \mathrm{O}$ strongly impacted by

30 seasonal light fluctuations, may be obtained by removing interannual $\delta^{18} \mathrm{O}$ only weakly affected by

31 light. Such features necessitate the reconstitution of tools frequently utilised, such as the coupled

$32 \quad \delta^{18} \mathrm{O}-\mathrm{Sr} / \mathrm{Ca}$ or pseudo-coral concepts.

33

\section{Introduction}

35 The oxygen isotope data preserved in the scleractinian coral skeleton is an excellent proxy for temperature and/or $\delta^{18} \mathrm{O}_{\text {seawater }}$ variability (McConnaughey, 1989), following the concept of isotopic thermometer (Urey, 1947). However, coral aragonite $\delta^{18} \mathrm{O}$ is depleted relative to the isotopic values of the ambient seawater (Weber and Woodhead, 1972), inducing anomalies commonly termed as vital effects. Therefore, we need to identify environmental parameters really included in the $\delta^{18} \mathrm{O}$ timeseries, the most-used coral skeleton proxy so far.

41 Because temperature and light intensities are always strongly related in the field, the real impact of 42 light on $\delta^{18} \mathrm{O}$ cannot be decoupled from the temperature effect. Although the relationship between 43 light and calcification has long been recognised (Goreau, 1959; Gattuso et al., 1999), the control of 44 ambient light level on the isotopic disequilibrium offset of coral aragonite from seawater could only be speculated upon (Land et al., 1975; McConnaughey, 1989; Felis, 2003). The role of light on coral $\delta^{18} \mathrm{O}$ can only be proved from evidence provided by cultured corals in controlled light conditions, all the other parameters remaining constant (Reynaud-Vaganay et al., 2001; Juillet-Leclerc and Reynaud, 2010). The latter authors show that at $25^{\circ} \mathrm{C}, \delta^{18} \mathrm{O}$ measured on Acropora clearly increases due to photosynthesis enhancement accompanying raised light intensity, while the skeleton exhibits noticeable infilling, accompanied by a reduced linear extension (Juillet-Leclerc and Reynaud, 2010).

51 In addition, temperature increase is also responsible for photosynthesis enhancement (Juillet-Leclerc et al., 2014). The comparison of biological measurements, such as net productivity and zooxanthellae density (Juillet-Leclerc et al., 2014) highlights the evidence, well known by biologists, that symbiont 
Biogeosciences Discuss., https://doi.org/10.5194/bg-2018-433

Manuscript under review for journal Biogeosciences

Discussion started: 19 October 2018

(c) Author(s) 2018. CC BY 4.0 License.

54 distribution on a coral is not homogeneous, varying with coral genera and coral morphology, ambient

55 vegetation in water column, water column depth and potential adaptations (Porter et al., 1984; Kühl et

56 al., 1995; Karako-Lampert et al., 2004; Iluz and Dubinsky, 2015). Juillet-Leclerc et al. (2014) deduced

that light should impact each temperature calibration and should be, likely to a large extent, responsible for the vital effect. In the field, according to location, temperature through the seasonality of precipitation and, in turn, nebulosity, is positively or negatively correlated to irradiation. Therefore, seasonal isotopic amplitude should not only reflect the temperature but the global effect of both temperature and light. Additionally, colonies collected on corals grown in the same location do not receive equivalent irradiation according to the water depth and their environment (Felis et al., 2003) and/or samples are not influenced by similar zooxanthellae density due to coral morphology (Land et al., 1974; JuilletLeclerc, 2014). Consequently, we supposed that $\delta^{18} \mathrm{O}$-temperature calibrations established from seasonal isotopic data are strongly impacted by local seasonality and/or characteristics of each colony. But calibrations based on annual data provided by one coral should not be similarly impacted by light as the seasonal data calculated from monthly samples. In turn, the pure temperature impact on $\delta^{18} \mathrm{O}$ cannot be quantified. Considering that light impacts coral $\delta^{18} \mathrm{O}$, what level of $\delta^{18} \mathrm{O}_{\text {seawater }}$ may be included in $\delta^{18} \mathrm{O}$ determination? Is there a hierarchy between temperature and light influence on $\delta^{18} \mathrm{O}$ ?

71 We intend to illustrate the different light effects on coral isotopic calibration versus temperature by using earlier published evidence. characterised by the unique sampling mode allowing the comparison of several annual coral genera calibrations. Second, we will compare seasonal calibrations estimated for several Porites colonies collected in warm and mediate-temperature water (Linsley et al., 1999; Maier et al., 2004; Quinn and Sampson, 2002). Third, we will show that seasonal and annual $\delta^{18} \mathrm{O}-$ temperature calibrations are not linearly related (Crowley et al., 1999; Boiseau et al., 1998). Then, understanding that the entanglement of environmental parameters and potential tracers captured in coral skeleton over the time imposes the 
Biogeosciences Discuss., https://doi.org/10.5194/bg-2018-433

Manuscript under review for journal Biogeosciences

Discussion started: 19 October 2018

(c) Author(s) 2018. CC BY 4.0 License.

81 the ways to circumvent what is hidden behind the blurred term 'vital effect' (Lowenstam and Weiner,

82 1989).

83

\section{Weber and Woodhead (1972) paper revisited}

85

86

87

88

89

90

91

\subsection{Data series}

Data published by Weber and Woodhead (1972), in the following referred to as WW72, remains one of the most exhaustive coral $\delta^{18} \mathrm{O}$ databases, although all the compiled data are not available in the publication. Our present knowledge may shed new light on the coral $\delta^{18} \mathrm{O}$-temperature dependence.

As early as 1951, Urey suspected that physiological processes could affect the $\delta^{18} \mathrm{O}$ of calcareous organisms, leading to values out of isotopic equilibrium with seawater, as shown by $\delta^{18} \mathrm{O}$ and $\delta^{13} \mathrm{C}$ measured in corals collected from Heron Island (Australia) (Weber and Woodhead, 1970). However, despite depleted $\delta^{18} \mathrm{O}$, these values showed apparent temperature dependence. In order to verify the coral skeleton's capability to capture temperature, they collected several coral genera spread over tropical oceans (Fig. 1a). WW72 data were used to establish a formula able to predict past SST following the isotopic thermometer concept (Urey 1947), expressed as:

$$
\mathrm{SST}^{\circ} \mathrm{C}=\mathrm{A}+\mathrm{B} \times \delta^{18} \mathrm{O}(\%)
$$

Annual temperature distribution from 21.2 to $29.3^{\circ} \mathrm{C}$ was prescribed by the 29 sites spread in the Pacific Ocean (except for two sites in the Atlantic and Indian oceans) (Fig. 1a). Several specimens of all the genera present on a site, at most 44 coral genera were collected; for example, 54 specimens of Acropora were collected on Heron Island (Great Barrier Reef) or 39 Porites in the Torres Strait (between Queensland and Papua New Guinea). Because Acropora and Porites are ubiquitous genera, Acropora $\delta^{18} \mathrm{O}$ calibration was derived from 835 samples and 421 samples of Porites. Derived calibrations (Fig. 1b) may be considered as statistically significant. In addition, isotopic analyses were conducted on annual samples, identified by X-ray growth bands, a pair of clear and dark bands corresponding to the annual growth (Barnes and Lough, 1996). 
Biogeosciences Discuss., https://doi.org/10.5194/bg-2018-433

Manuscript under review for journal Biogeosciences

Discussion started: 19 October 2018

(c) Author(s) 2018. CC BY 4.0 License.

108 Since the goal of the WW72 study was to verify the relationship between $\delta^{18} \mathrm{O}$ and SST to predict SST

109 (Epstein 1951, 1953), they established the calibration of temperature relative to $\delta^{18} \mathrm{O}: \mathrm{PT}=$

110 'paleotemperature curve' i.e. the temperature expressed according to $\delta^{18} \mathrm{O}_{\text {carbonate }}$ or as reported in

111 Table 4 from the WW72 formula Eq. (1) (Fig. 1b). In this study, the authors neglected the term

$112 \delta^{18} \mathrm{O}_{\text {seawater. }}$ However, in 1972 , the annual instrumental temperature precision was much greater than

$113 \delta^{18} \mathrm{O}_{\text {carbonate }}$ measurement precision. To date, our purpose is not to prove the existence of an isotopic

114 thermometer but rather to check the reliability of the relationship between $\delta 18$ Ocarbonate and SST.

115 Therefore, we calculated the relationship:

116

$$
\delta^{18} \mathrm{O}_{\text {carbonate }}=\mathrm{a} \times \operatorname{SST}\left({ }^{\circ} \mathrm{C}\right)+\mathrm{b}
$$

117 where a and $\mathrm{b}$ are constants (Fig. 1c), considering that the variable is SST.

118 We are aware that by inverting (1) into (2), from the same dataset, the obtained relationship has not 119 equivalent significance and similar errors in the constants than the relationship calculated from 120 initially published calibrations.

\subsubsection{Calibrations including $\delta^{18} O_{\text {seawater }}$}

123

The WW72 dataset does not take into account $\delta^{18} \mathrm{O}_{\text {seawater. Juillet-Leclerc and Schmidt }}(2001)$ included annual $\delta^{18} \mathrm{O}_{\text {SeaWater }}$ values assessed in the calibration established for Porites following the formula:

$$
\delta^{18} \mathrm{O}_{\text {carbonate }}-\delta^{18} \mathrm{O}_{\text {seawater }}=\alpha \times \operatorname{SST}\left({ }^{\circ} \mathrm{C}\right)+\beta
$$

where $\alpha$ and $\beta$ are constants. They obtained:

$$
\delta^{18} \mathrm{O}_{\text {carbonate }}-\delta^{18} \mathrm{O}_{\text {seawater }}=-0.20 \times \operatorname{SST}\left({ }^{\circ} \mathrm{C}\right)+0.45
$$
with $\mathrm{R}^{2}=0.83, \mathrm{~N}=22, \mathrm{p}<0.001$, only significant over the SST range from 24 to $30^{\circ} \mathrm{C}$ (JuilletLeclerc and Schmidt, 2001), by introducing $\delta^{18} \mathrm{O}_{\text {seawater }}$ following two estimates (Fig. 2). The correlation linking $\delta^{18} \mathrm{O}$ directly to temperature showed a higher coefficient:

$$
\delta^{18} \mathrm{O}_{\text {carbonate }}=-0.27 \times \operatorname{SST}\left({ }^{\circ} \mathrm{C}\right)+2.24
$$
with $\mathrm{R}^{2}=0.91, \mathrm{~N}=24, \mathrm{p}<0.001$ (Fig. 1c) including the lowest temperatures neglected in Eq. (4) (Juillet-Leclerc and Schmidt, 2001). 
Biogeosciences Discuss., https://doi.org/10.5194/bg-2018-433

Manuscript under review for journal Biogeosciences

Discussion started: 19 October 2018

(c) Author(s) 2018. CC BY 4.0 License.

134 A similar procedure was conducted for Acropora, using the same $\delta^{18} \mathrm{O}_{\text {seawater }}$ estimates. We obtained:

$$
\delta^{18} \mathrm{O}_{\text {carbonate }}-\delta^{18} \mathrm{O}_{\text {seawater }}=-0.21 \times \mathrm{SST}\left({ }^{\circ} \mathrm{C}\right)+1.26
$$

136 with $\mathrm{R}^{2}=0.87, \mathrm{~N}=24, \mathrm{p}<0.001$ significant over the temperature range from 21 to $30^{\circ} \mathrm{C}$ (Fig. 2). In

137 contrast, Porites isotopic values associated to the lowest temperatures are included in the calibration.

138 The correlation linking $\delta^{18} \mathrm{O}$ and temperature showed a higher coefficient:

$$
\delta^{18} \mathrm{O}_{\text {carbonate }}=-0.28 \times \mathrm{SST}\left({ }^{\circ} \mathrm{C}\right)+3.36
$$

with $\mathrm{R}^{2}=0.97, \mathrm{~N}=24, \mathrm{p}<0.001$ (Fig. 2).

141 Slopes (a) shown by Porites and Acropora temperature calibrations including $\delta^{18} \mathrm{O}_{\text {seawater, }}-0.20$ and $0.21 \% /{ }^{\circ} \mathrm{C}$ respectively differ from those deriving only from $\delta^{18} \mathrm{O}_{\text {carbonate }}$ and temperature. They are close to the slope of $-0.19 \% /{ }^{\circ} \mathrm{C}$ assessed for inorganic aragonite calibration (Kim et al., 2007). Slopes have been obtained from other genera such as Platygira, Montipora or Pavona (Fig. 2) in different temperature ranges and with variable correlation coefficients. The number of analysed specimens is reduced compared to Acropora or Porites calibrations (WW72).

\subsubsection{Relationship between $a$ and $b$}

When comparing constants (a) and (b) from equation (2) for all the genera annual $\delta^{18} \mathrm{O}$ versus annual temperature of theWW72 data series, we obtained a strongly significant linear relationship:

$$
b=-27.9 a-5.13
$$
with $\mathrm{R}^{2}=0.95, \mathrm{~N}=29$ and $\mathrm{p}<0.001$. We verified that after neglecting extreme values of (b), the relationship remained significant $\left(\mathrm{R}^{2}=0.90, \mathrm{~N}=26\right.$ and $\left.\mathrm{p}<0.001\right)$ (Fig. 3a). Such a relationship is not hazardous, but reflects inherent features of annual coral $\delta^{18} \mathrm{O}$-annual temperature calibrations. We observed in Fig. 1c that some curves converged, defining several bundles. All the groups, formed by genera gathered in the same bundle, are listed in Table 1. In Fig. 1d, we underline that, for example for Acropora and Porites groups, the convergence corresponds to quantified temperature and isotopic value ranges. When comparing constants of calibrations corresponding to a group, we obtained linear relationships, all showing highly significant correlation coefficients: $\mathrm{R}^{2}=0.99$ (Fig. 3b). 
Biogeosciences Discuss., https://doi.org/10.5194/bg-2018-433

Manuscript under review for journal Biogeosciences

Discussion started: 19 October 2018

(c) Author(s) 2018. CC BY 4.0 License.

\subsection{Improved meaning of annual calibration from WW72}

162 Each temperature value, corresponding to one island, is associated to the averaged $\delta^{18} \mathrm{O}$ measured for

163 corals of the same species, all receiving identical local irradiation. However, several colonies of a

164 same genus might be subjected to different light incidence, intensity depending to relative growth depth, or corals included in the same local environmental could have morphological portion containing higher or lower zooxanthellae distribution or potential adaptation (Porter et al., 1984; Kühl et al., 1995; Karako-Lampert et al., 2004; Iluz and Dubinsky, 2015). WW72 data corresponding to each temperature correspond to colonies numerous enough to represent a quasi-homogenous irradiation. This explains that calibrations assessed for all genera may be significantly compared without taking into account light conditions (Fig. 1). Only these conditions allow the comparison of calibrations assessed for several coral genera.

\subsubsection{Temperature dependence of coral $\delta^{18} \mathrm{O}$}

$174 \quad$ 2.2.1.1 Temperature recorded at least twice

$175 \delta^{18} \mathrm{O}$ temperature dependence expressed as Eq. (2) stresses the strong temperature effect on isotopic 176 fractionation but this formula excludes $\delta^{18} \mathrm{O}_{\text {seawater }}$ displayed in the classical thermodynamic expression

177 Eq. (6). After introducing $\delta^{18} \mathrm{O}_{\text {seawater }}$ into WW72 data, for some genera, Porites and Acropora genera

178 (Fig. 2), we observed that the usual thermodynamic equation is also significant but to a lower degree;

179 for example by taking into account only temperature, $R^{2}=0.91$ and 0.98 instead of $R^{2}=0.87$ and 0.93

180 for Porites and Acropora respectively, for the usual thermodynamic equation.

181 In the calibrations depending only on temperature, temperature may act first, according to 182 thermodynamic law (Epstein et al., 1953; Juillet-Leclerc et al., 2014) and second, through the 183 photosynthetic process (Juillet-Leclerc and Reynaud, 2010), which is enhanced by a temperature 184 increase. However, an increase in temperature induces a decrease in $\delta^{18} \mathrm{O}$ following the first process 185 while the second mechanism causes a rise in $\delta^{18} \mathrm{O}$ confusing the global isotopic effect. Temperature 186 influences $\delta^{18} \mathrm{O}$ twice, explaining that temperature is the main factor on isotopic value determination, which does not exclude the role of $\delta^{18} \mathrm{O}_{\text {seawater. }}$. 
Biogeosciences Discuss., https://doi.org/10.5194/bg-2018-433

Manuscript under review for journal Biogeosciences

Discussion started: 19 October 2018

(c) Author(s) 2018. CC BY 4.0 License.

2.2.1.2 Annual coral $\delta^{18} \mathrm{O}$ contains $\delta^{18} \mathrm{O}_{\text {seawater }}$

190 Calibrations taking into account $\delta^{18} \mathrm{O}_{\text {seawater }}$ exhibit a slope value close to that calculated for isotopic equilibrium of inorganic aragonite with water, suggesting that under quasi-uniform light, the isotopic offset of coral $\delta^{18} \mathrm{O}$ (the difference between coral $\delta^{18} \mathrm{O}$ and value at isotopic equilibrium) is constant, regardless of temperature (Fig. 2).

Calibration deduced for Porites is restricted to temperatures higher than $25^{\circ} \mathrm{C}, \delta^{18} \mathrm{O}$ corresponding to lowest temperatures being too high to be included on the strongly significant linear curve. For the other genera, $\mathrm{n}$ is limited by the lack of these coral colonies on numerous islands.

Equations (4) and (6) confirm that, to a lesser degree than temperature, $\delta^{18} \mathrm{O}_{\text {seawater }}$ may be included in annual coral skeleton $\delta^{18} \mathrm{O}$.

\subsubsection{Relationship between constants $a$ and $b$}

WW72 data reveal a strong relationship between annual $\delta^{18} \mathrm{O}-$ annual temperature calibrations and taxonomy because each genus shows a unique relationship. Calibration bundles defining groups (Table 1) enhance this feature. Coral genera classification or taxonomy is based on coral morphology. Land et al. (1975) stressed the high $\delta^{18} \mathrm{O}$ variability following the longitudinal section on the calices of Eusmilia fastigiata or the septa dentations of Scolymia cubensis inducing coral skeleton isotopic variations. The authors observed that according to coral location some skeleton portions might be more or less developed, implying a large isotopic variability.

Considering the relationship $\delta^{18} \mathrm{O}_{\text {carbonate }}=\mathrm{a} \times \mathrm{SST}\left({ }^{\circ} \mathrm{C}\right)+\mathrm{b}$ Eq. (2) derived from the WW72 dataset,

210 (a), the slope value, varies from -0.16 to -0.36 . This corresponds to a disequilibrium indicator 211 compared to -0.19 , the slope value derived from the theoretical $\delta^{18} \mathrm{O}$-temperature equation at equilibrium (Kim et al., 2007). The equation (7) exhibits that the constants (a) and (b) of annual $\delta^{18} \mathrm{O}-$ 
Biogeosciences Discuss., https://doi.org/10.5194/bg-2018-433

Manuscript under review for journal Biogeosciences

Discussion started: 19 October 2018

(c) Author(s) 2018. CC BY 4.0 License.

$215 \mathrm{p}<0.001$. This suggests that the temperature dependence of isotopic oxygen ratio is based on a unique

216 rationale according to taxonomy, inherent to the coral skeleton.

217

218

\subsubsection{Common feature of $\delta^{18} \mathrm{O}$ and $\mathrm{Sr} / \mathrm{Ca}$ calibrations}

A similar relationship exists between the constants of annual coral skeleton $\mathrm{Sr} / \mathrm{Ca}$-annual temperature calibration (Marshall and McCulloch, 2002; Wei et al., 2007; Deng et al., 2014; D’Olivio et al., 2018), another temperature tracer present in the coral skeleton. There is no straightforward link between $\delta^{18} \mathrm{O}$, oxygen being a component of $\mathrm{CaCO} 3$ and $\mathrm{Sr}$, an impurity included in the skeletal aragonite. However, it is possible to recognise common $\delta^{18} \mathrm{O}$ and $\mathrm{Sr} / \mathrm{Ca}$ behaviour relative to their crystalline unit distribution in the coral skeleton and the concept of taxonomy.

\subsubsection{Role of crystalline microstructures}

It is admitted that the coral skeleton presents composite mineral microstructures: centres of calcification (COC) and fibres, embedded in a few organic matter as a network (Von Euw et al., 2017). These crystalline elements are distributed differently according to morphology (Cuif and Dauphin, 1978, 2005; Stolarski, 2003; Nothdurft and Webb, 2005). The latter authors showed that each microstructure is preferentially present in some morphological parts, which are more or less developed following the genus. On one hand, $\delta^{18} \mathrm{O}$ signature differs according to the microstructure unit (Rollion-Bard et al., 2003; Blamart et al., 2005; Meibom et al., 2006; Juillet-Leclerc et al., 2009), the $\mathrm{COC} \delta^{18} \mathrm{O}$ value being lower than that of the fibre. On the other hand, $\mathrm{Sr} / \mathrm{Ca}$ ratios measured on COCs are higher than those of fibres (Meibom et al., 2006; Cohen et al., 2001). Meibom et al. (2006) sampled Colpophyllia sp. following microstructures on a skeleton morphology fragment and their $\mathrm{Sr} / \mathrm{Ca}$ data of each crystal type show convergence. Cohen et al. (2001) examined synchronously deposited microstructures on Porites lutea over a year, exhibiting COC elemental ratios systematically higher compared to those of fibres developed over an identical period. Thus, the annual $\mathrm{COC} \mathrm{Sr} / \mathrm{Ca}$ value is higher than the annual fibre $\mathrm{Sr} / \mathrm{Ca}$ signature (Cohen et al., 2001). Therefore, we suggest that discrepancies of morphology existing between coral genera are due to differences of microstructure 
Biogeosciences Discuss., https://doi.org/10.5194/bg-2018-433

Manuscript under review for journal Biogeosciences

Discussion started: 19 October 2018

(c) Author(s) 2018. CC BY 4.0 License.

proportions. Therefore, differences in geochemical values due to the relative number of microstructures could explain common features between the annual trace element ratio and annual $\delta^{18} \mathrm{O}$-annual temperature calibrations, especially the linear relationship linking the respective calibration constants.

\subsubsection{Notion of optimal growth}

248 We already identified groups of genera (Table 1) showing constants (a) and (b) from calibrations of 249 genera linked by strong correlation coefficient $\left(\mathrm{R}^{2}=0.99\right)$ (Fig. 3b). This could be due to morphology similarities of the genera of each bundle, characterised by identical proportions of microstructures in each coral group skeleton. We previously highlighted the intersection of calibrations defined by

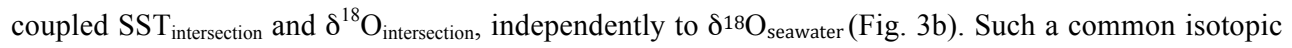
composition can be obtained because light intensity is homogenised. Coupled values SST $_{\text {intersection }}$ and $\left.\delta^{18} \mathrm{O}_{\text {intersection}}\right)$ might be related to the concept of the optimal growth conditions (Jokiel and Coles, 1977) attributed to an optimal growth temperature.

256 An optimal temperature, between 25 and $29^{\circ} \mathrm{C}$, corresponding to an optimal growth rate has been attributed to some coral genera, Montipora verrucosa, Pocillopora damicormis, Fungia scutaria (Jokiel and Coles, 1977). However, it was difficult to identify a temperature value corresponding to optimal growth conditions: is maximal extension rate or density considered as representative of optimal growth rate (Carricart-Ganivet et al., 2004; Worum et al., 2007; Brachert at al., 2013)? This concept could also be linked to the temperature corresponding to the maximal $\mathrm{Ca}^{2+}$ input in the coral skeleton, as has been identified by Al-Horani (2005). Optimal growth temperature differs according to coral genus (Buddemeier and Kinzie III, 1976; Marshall and Clode, 2004). The latter authors relate the temperature dependence of the optimal growth rate of Galaxea facsicularis to an enzyme-catalysed reaction, but they finally conclude that the response of calcification rate to temperature being similar in zooxanthellate and azooxanthellate corals, the responsible mechanism should be based on another 
Biogeosciences Discuss., https://doi.org/10.5194/bg-2018-433

Manuscript under review for journal Biogeosciences

Discussion started: 19 October 2018

(c) Author(s) 2018. CC BY 4.0 License.

suggest that $26.7^{\circ} \mathrm{C}$ could be the thermal optimum of calcification rate for this genus, which could be compared with our $\mathrm{SST}_{\text {intersection }}$ identified for Porites, of $28.4^{\circ} \mathrm{C}$. From our evidence, $\mathrm{SST}_{\text {intersection }}$ corresponds to $\delta^{18} \mathrm{O}_{\text {intersection }}$ shared by a coral group and is related to morphology and growth rate (Land et al., 1975), likely related to optimal growth. Assuming that relative amounts of crystalline units are responsible for the constant relationship of the annual $\delta^{18} \mathrm{O}-$ annual temperature calibration, we have to assume that at this temperature, identical $\delta^{18} \mathrm{O}$ is due to the same relative crystalline amounts in the coral skeleton, whatever is the considered genus belonging to the same group (Table 1) or, more probably, a temperature range corresponding to an isotopic range (Fig. 1d). For example, the coupled $\mathrm{SST}_{\text {intersection }}$ and $\delta^{18} \mathrm{O}_{\text {intersection }}$ could represent common values shared by all Acropora or Porites colonies whatever is the site where they grow (Fig. 3).

The following conclusions concern all coral genera studied in WW72 and their annual $\delta^{18} \mathrm{O}-$ calibrations. Temperature prevails on $\delta^{18} \mathrm{O}$ because it influences $\delta^{18} \mathrm{O}$ in two ways, first it acts as is thermodynamically predicted, implying a $\delta^{18} \mathrm{O}$ decrease and second it induces an enhancement of photosynthesis causing a $\delta^{18} \mathrm{O}$ increase. Similar behaviour of the constants of the annual $\delta^{18} \mathrm{O}$ and $\mathrm{Sr} / \mathrm{Ca}$-annual temperature calibrations should be explained by the presence of two crystallographic components of the coral skeleton, showing specific COC-to-fibre proportions for each genus, depending on their morphology and characterised by their respective geochemical signatures. We deduce from WW72 data that all the coral genera are potential temperature tracers. range corresponding to optimal growth rate.

\section{Porites monthly calibration}

291 The first seasonal $\delta^{18} \mathrm{O}$ records were measured for Montastrea annularis (Fairbanks and Dodge, 292 1979). Seasonal $\delta^{18}$ O profiles from Porites grown in the Galapagos (McConnaughey, 1989) were used 
Biogeosciences Discuss., https://doi.org/10.5194/bg-2018-433

Manuscript under review for journal Biogeosciences

Discussion started: 19 October 2018

(c) Author(s) 2018. CC BY 4.0 License.

293 to assess seasonal $\delta^{18} \mathrm{O}-$ seasonal temperature calibration. Presently, such a regression is commonly

294 calculated.

295 The preliminary step of climatic reconstruction using Porites skeleton, the genus more often analysed

296 in this context, consists of the assessment of seasonal $\delta^{18} \mathrm{O}-$ seasonal temperature calibration based on monthly instrumental temperatures over the last decades covered by the core. Sampling is conducted along the coral's growth through time, following the maximal growth rate perpendicular to the annual density bands shown by X-ray (DeLong et al., 2013). In order to test seasonal $\delta^{18} \mathrm{O}$-seasonal temperature calibration variability including the seasonal light effect, calculated for several coral cores collected on a given site, at different temperature ranges, we considered studies conducted on several Porites colonies from three sites. The mean annual temperature offshore Amédée Island, New Caledonia $\left(22^{\circ} 29^{\prime} \mathrm{S}, 166^{\circ} 28^{\prime} \mathrm{E}\right)$ was $24.72^{\circ} \mathrm{C}$, over the period 1968-1992 (Quinn and Sampson, 2002; Stephans et al., 2004), while at Clipperton Atoll (10 $18^{\prime} \mathrm{N}, 109^{\circ} 13^{\prime} \mathrm{W}$ ) the mean annual temperature was $28.5^{\circ} \mathrm{C}$, over the period $1985-1995$ (Linsley et al., 1999, 2000) and in the Flores Sea, Indonesia $\left(6^{\circ} 32^{\prime} \mathrm{S}, 121^{\circ} 13^{\prime} \mathrm{E}\right)$ the mean annual temperature was above $28^{\circ} \mathrm{C}$, over the period $1979-1985$ (Maier et al., 2004).

\subsection{Data in the three sites}

\subsubsection{Calibrations from New Caledonia data}

311 Calibrations have been calculated for two paths of a long core 92 and 99-PAA and two short cores 92-

312 PAC and 92-PAD, collected from Porites lutea, compared to the appropriate grid square GISST2 313 temperature from 1968 to 1992 (Quinn and Sampson, 2002; Stephans et al., 2004). These data are 314 available on https://www.ncdc.noaa.gov/paleo/study/1877. Seasonal temperature varied from 21.5 to $31527.5^{\circ} \mathrm{C}$, values lower than the $\mathrm{SST}_{\text {intersection }}$ estimated for Porites, of $28.4^{\circ} \mathrm{C}$. Precipitation did not show any preferential seasonality. The $\delta^{18} \mathrm{O}$ record from all the cores displayed a clear seasonal cycle

317 (Quinn and Sampson, 2002; Stephans et al., 2004). All the calibrations given following Eq. (2) 318 showed higher slope than -0.19 , the slope value derived from the theoretical $\delta^{18} \mathrm{O}-$ 
Biogeosciences Discuss., https://doi.org/10.5194/bg-2018-433

Manuscript under review for journal Biogeosciences

Discussion started: 19 October 2018

(c) Author(s) 2018. CC BY 4.0 License.

-0.17 (Fig. 4a, 4b). When comparing (a) and (b) from the calibrations, a strongly correlated relationship is obtained (Table 2) (Fig. 4c).

322

324 We considered three Porites cores (Linsley et al., 1999; 2000) whose data are provided on 325 https://www.ncdc.noaa.gov/paleo/study/1846. Over the last decade, annual temperature varied less 326 than $2{ }^{\circ} \mathrm{C}$ (Reynolds and Smith, 1994), showing a mean value of $28.5^{\circ} \mathrm{C}$ and a clear seasonal cycle 327 (Linsley et al., 1999; 2000). Maximum lag between $\delta^{18} \mathrm{O}$ and temperature is at least 1 month, occasionally up to 2 months (Linsley et al., 1999; 2000).

Expressed following Eq. (2), calibrations showed low slopes, compared to -0.19 , the slope value derived from the theoretical $\delta^{18} \mathrm{O}-$ temperature relationship at equilibrium (Kim et al., 2007), varying between -0.4 and $-0.53 \% /{ }^{\circ} \mathrm{C}$ (Fig. $5 \mathrm{a}, 5 \mathrm{~b}$ ), (a) and (b) being strongly correlated (Table 2) (Fig. 5c).

\subsubsection{Calibration from the Flores Sea}

334 Twelve pathways collected on six coral heads from three Porites species (Porites lutea, Porites murrayensis and Porites australiensis) (Fig. 6a, 6b) provide 12 calibrations given following equation (2) covering 55 months and converted into Eq. (3) (Maier et al, 2004). In the site located at the western margin of the Warm Pool, the mean annual temperature is $28^{\circ} \mathrm{C}$ with an annual amplitude of $2.5^{\circ} \mathrm{C}$. Although the assessed constants are known to be not free of errors, the relationship established between (a) and (b) showed a highly significant correlation coefficient (Table 2) (Fig. 6c, 6d). It is noticeable that several Porites species were considered.

341 We display together all the Porites calibrations previously mentioned in Fig. 7a and equation corresponding to Porites group V from WW72, covering high temperature amplitude and

343 disequilibrium indicator range. The values of the constants (a) and (b) of all the calibrations are 344 reported in Fig. 7b. The correlation coefficient of the linear regression is $0.999, \mathrm{~N}=25$. 
Biogeosciences Discuss., https://doi.org/10.5194/bg-2018-433

Manuscript under review for journal Biogeosciences

Discussion started: 19 October 2018

(c) Author(s) 2018. CC BY 4.0 License.

\subsection{Significance of the constants of $\delta^{18} \mathrm{O}$-temperature calibrations derived from} monthly data.

348 We assume that calibrations measured on different coral colonies grown at a given site (New Caledonia, Clipperton or Indonesia) differ according to various light sensitivities due to depth or light incidence or acclimation (Fig. 7a) because seasonality strongly affects light variations, and is likely to be different following site location. However, calibration constants calculated from monthly data for Porites remain strongly correlated (Fig. 7b) as we observed for annual $\delta^{18} \mathrm{O}$-annual temperature calibrations (2.2.2).

\subsubsection{Local effects on $\delta^{18} \mathrm{O}$}

356 The isotopic characteristics may be explained by local conditions. In New Caledonia the mean annual temperature, $24.72{ }^{\circ} \mathrm{C}$, is lower than the temperature intersection estimated for Porites group from WW72 (Fig. 4) of $28.4^{\circ} \mathrm{C}$, the annual amplitude being $6^{\circ} \mathrm{C}$. To justify the weak slope of the calibrations, we argue that maximal annual temperature and high light are synchronous: thus, the $\delta^{18} \mathrm{O}$ decrease due to temperature being reduced during boreal summer and during winter is normal. Therefore, the annual isotopic amplitude is limited. 92PAC and 99PAA show strong attenuation in boreal summer (Fig. 4a), which could be related to strong photosynthetic activity. However these coral cores also exhibit low $\delta^{18} \mathrm{O}$ during winter according to lower slopes of calibrations for 92PAC and 99PAA compared to 92PAC and 92PAD (Fig. 4b).

However, in Clipperton and in Indonesia, the mean annual temperature is about $28^{\circ} \mathrm{C}$ with a weak annual temperature amplitude (about $2^{\circ} \mathrm{C}$ ). In these conditions, the disequilibrium indicator (a) varies from -0.6 to -0.4 (Fig. $7 b$ ). The temperature range in Clipperton and the Flores Sea is close to the temperature intersection estimated for Porites group from WW72, at $28.4^{\circ} \mathrm{C}$ (Fig. 5 and Fig. 6 respectively). In Indonesia, slope (a) shows much higher range, from -0.4 to -1 than at Clipperton.

370 Maier et al. (2004) stress that calibrations are calculated from several Porites species (Fig. 6). The 371 authors also observe negative correlation between mean annual coral $\delta^{18} \mathrm{O}$ and annual linear skeletal extension. 
Biogeosciences Discuss., https://doi.org/10.5194/bg-2018-433

Manuscript under review for journal Biogeosciences

Discussion started: 19 October 2018

(c) Author(s) 2018. CC BY 4.0 License.

\subsubsection{Correlation of the constants derived for monthly $\delta^{18} O$-temperature calibrations}

375
Relationships calculated from monthly data measured in Indonesia (Fig. 6) and Clipperton (Fig. 5) corals (Maier et al., 2004; Linsley et al., 1999) are almost the same. This could be due to the identical temperature range (from 26 to $29^{\circ} \mathrm{C}$ ). As calibrations do not obey only thermodynamic rules, $\delta^{18} \mathrm{O}_{\text {seawater }}$ is neglected. The relationships linking (a) and (b) do not depend on local environmental parameters and seem to be inherent to Porites calcification, as we noticed for annual calibrations (2.2.1.1). Furthermore, calibration constants deduced from New Caledonia corals, subject to drastically different external conditions from in the other sites, follow the same linear relationship (Table 2) (Fig. 7a, b). Moreover, the constants calculated for annual data of Porites derived from WW72 are included in the linear relationship (Fig. 7b). The relationship $b=-27.24$ and a -4.92 (established with $\mathrm{N}=19, \mathrm{R}^{2}=0.999$ ) Eq. (7) (Fig. 7b) reflects Porites skeleton crystallisation, regardless of other external conditions, including light.

However, we demonstrated that light affected cultured Acropora (Juillet-Leclerc and Reynaud, 2010). Is such a behaviour only restricted to Acropora? The latter authors attributed this feature to the existence of two distinct crystallisation modes of $\mathrm{COC}$ and fibres, which are common to other Acropora species (Gladfelter, 1982) but also to other genera (Jell, 1974).

Therefore, constants of monthly $\delta^{18} \mathrm{O}$-monthly temperature calibrations show a strong relationship (Fig. 7) due to crystalline distribution of the coral skeleton, COCs being fusiform crystals deposited according to temperature, regardless of light intensity, ensuring linear extension whereas fibres formation ensuring infilling is light- and temperature-dependent (Gladfelter, 1982; Juillet-Leclerc and Reynaud, 2010; Juillet-Leclerc et al., 2018). We have already highlighted that the relationship linking constants of annual $\delta^{18} \mathrm{O}$-annual temperature calibration is due to the relative numbers of crystalline units present in the coral skeleton, including both temperature-dependent crystals, COC and fibres also light-dependent crystals. By considering Fig.7b, only constants from New Caledonia calibration show slope (a) values higher than -0.19 , the slope value derived from the theoretical $\delta^{18} \mathrm{O}-$ temperature relationship at equilibrium (Kim et al., 2007), corresponding to coral fragments where 
Biogeosciences Discuss., https://doi.org/10.5194/bg-2018-433

Manuscript under review for journal Biogeosciences

Discussion started: 19 October 2018

(c) Author(s) 2018. CC BY 4.0 License.

400 fibres are in higher numbers than COCs, whereas the other slope values lower than -0.19 correspond

401 to coral portions where COC numbers are higher than fibres.

Considering seasons over a year, an increase (decrease) of temperature induces $\delta^{18} \mathrm{O}$ decrease

(increase), and temperature increase (decrease) induces $\delta^{18} \mathrm{O}$ increase (decrease) through photosynthetic increase (decrease) with increasing (decreasing) temperature (Juillet-Leclerc and Reynaud, 2010; Juillet-Leclerc et al., 2014).

406

Therefore, for Porites, when absolute value of the slope exceeds the absolute value of the quasiequilibrium $\mathrm{a}=-0.20(\mathrm{~b}=0.46)$ obtained from WW72 data, the value of (a) corresponds to numbers of COCs compared to fibres due to high temperature, explaining that coral skeleton $\delta^{18} \mathrm{O}$ decreases when coral linear extension increases (Maier et al., 2004).

411 At every temperature, for annual or monthly resolution, regardless of external conditions, the

412 distribution of microstructures creates linear relationships between the constants of calibrations of

413 Porites, in turn causing density fluctuations (Gladfelter, 1982; Lough and Cooper, 2011).

\subsubsection{Role of growth rates}

RX images of the cores measured on New Caledonia have been published (DeLong et al., 2013) where

417 we can see the presence of clear annual banding. However, intra-annual variations of density cannot

418 be recognised. Only careful identification of seasonal temperature fluctuations, with the sampling path reported on the RX image, could provide detailed information. But we know that even when the seasonal density variation is high (Buigues and Bessat, 2001; Lough and Cooper, 2011; Lough and Cantin, 2014) we cannot attribute clear seasonality to the density change.

DeLong et al. (2013) stress the importance of the orientation of the growth axis, the corallite distribution and also the distance between density bands underlined by X-rays, knowing that a pair of dark and clear layers indicates a year's deposit (Barnes and Lough, 1996). X-rays could provide information about coral growth rates and the density resulting from the interplay of extension and 
Biogeosciences Discuss., https://doi.org/10.5194/bg-2018-433

Manuscript under review for journal Biogeosciences

Discussion started: 19 October 2018

(c) Author(s) 2018. CC BY 4.0 License.

427

examination of coral growth characteristics in conjunction with geochemical analyses of the same material can greatly enhance the environmental information obtained from coral archives. It is now admitted that skeletal density results from the interplay of several factors, especially temperature and light (Tudhope, 1994; Juillet-Leclerc et al., 2006).

As early as 1982, Gladfelter assumed that linear extension and infilling are two independent growth rates, an assumption supported by Juillet-Leclerc and Reynaud (2010). The authors demonstrated that each growth rate is related to preferential deposition of microstructures, COCs ensuring linear extension and fibres, infilling. Furthermore, geochemical investigations reveal that crystal isotopic signatures differ (Rollion-Bard et al., 2003; Maier et al., 2004; Blamart et al., 2005; Meibom et al., 2006; Juillet-Leclerc et al., 2009). COC formation should be related to temperature (Gladfelter, 1984) and fibre deposit depends on both temperature and light (Juillet-Leclerc et al., 2018). Therefore, temperature and light changes interplay to determine skeletal isotopic composition.

Sampling conducted as it is described in DeLong et al. (2013) includes both COCs and fibres. Changes of relative amounts of microstructure as illustrated by X-rays and their respective $\delta^{18} \mathrm{O}$ are determined by their mechanisms of formation, unknown so far (Juillet-Leclerc et al., 2009). Following isotopic laws, the combination of calcification processes and isotopic fractionation could be expressed as:

$$
\text { measured } \delta^{18} \mathrm{O}=\left[\left(\mathrm{x}_{\mathrm{COC}} \times \delta^{18} \mathrm{O}_{\mathrm{COC}}\right)+\left(\mathrm{x}_{\text {fibre }} \mathrm{x} \delta^{18} \mathrm{O}_{\text {fibre }}\right)\right] /\left(\mathrm{x}_{\mathrm{COC}}+\mathrm{x}_{\text {fibre }}\right)
$$

where $\mathrm{x}_{\mathrm{COC}}$ and $\mathrm{x}_{\text {fibre }}$ are the relative amounts of the crystal microstructures, with $\mathrm{x}_{\mathrm{COC}}+\mathrm{x}_{\mathrm{fibre}}=1$, and $\delta^{18} \mathrm{O}_{\mathrm{COC}}$ and $\delta^{18} \mathrm{O}_{\text {fibre }}$ are their isotopic signatures depending on temperature and temperature and light, respectively. This expression is likely to be simplistic but closer to the truth than thermodynamic formula. Temperature is the prominent factor because included both in the crystal amounts and the isotopic signatures.

$\mathrm{SST}_{\text {intersection }}$ and the corresponding $\delta^{18} \mathrm{O}_{\text {intersection }}$ should be related to morphology (Land et al., 1975). When using relationship (8), measured $\delta^{18} \mathrm{O}=\left(\mathrm{x}_{\mathrm{COC}} \times \delta^{18} \mathrm{O}_{\mathrm{COC}}\right)+\left(\mathrm{x}_{\text {fibre }} \times \delta^{18} \mathrm{O}_{\text {fibre }}\right)$, the intersection of calibration should be obtained when $\delta^{18} \mathrm{O}_{\text {intersection }}=\left(0.50 \times \delta^{18} \mathrm{O}_{\mathrm{COC}}\right)+\left(0.50 \times \delta^{18} \mathrm{O}_{\text {fiber }}\right)$ or at $\mathrm{SST}_{\text {intersection }}, \delta^{18} \mathrm{O}_{\text {intersection }}=\left(\delta^{18} \mathrm{O}_{\mathrm{COC}}+\delta^{18} \mathrm{O}_{\text {fibre }}\right) / 2$. As long as temperature does not reach $\mathrm{SST}_{\text {intersection }}$ 
Biogeosciences Discuss., https://doi.org/10.5194/bg-2018-433

Manuscript under review for journal Biogeosciences

Discussion started: 19 October 2018

(c) Author(s) 2018. CC BY 4.0 License.

progressively prevailing.

457 The relationship linking constants (a) and (b) of monthly $\delta^{18} \mathrm{O}$ and temperature seems to be inherent to

458 Porites calcification. Slope or (a) ranges between -0.14 to -0.93 , surrounding -0.19 , the slope value derived from the theoretical $\delta^{18} \mathrm{O}$-temperature relationship at equilibrium (Kim et al., 2007). Variability of (a) is essentially due to the opposite isotopic effect of simultaneous temperature and light occurring during the year. Considerations of coral calibrations established from annual and monthly $\delta^{18} \mathrm{O}$ and temperature, reveal the robustness of temperature dependence on isotopic composition and also highlight the role of intra-annual aragonite density in $\delta^{18} \mathrm{O}$ determination. We conclude that calibrations cannot be explained by simple thermodynamic calculation but need information about calcification processes and microstructure (COC and fibre) isotope signatures, depending on temperature and light.

\section{$4 \delta^{18} \mathrm{O}$ non-linearity over time}

\subsection{Data}

\subsubsection{New Caledonia}

Crowley et al. (1999) highlighted $\delta^{18} \mathrm{O}$ non-linearity over time for Porites from isotopic data series measured on a core collected at Phare Amédée (New Caledonia) (Quinn et al., 1998), where cores were also collected for calibrations calculated by Stephans et al. (2004) (paragraph 3.1.1) (Fig. 4). Crowley et al. (1999) assessed the seasonal calibration established with four samples per year over 22 years. Then, from this calibration, they predicted temperature variations from 1900 until 1992, which they compared with $20^{\text {th }}$ century GISST2 observed temperatures (Parker et al., 1995) following the same resolution. The calibration cannot be validated, predicted temperatures over 1900-1950 being underestimated against observed temperatures. Crowley et al. (1999) noticed that by using annual calibration, the temperature prediction shows better agreement than that derived from monthly calibration. 
Biogeosciences Discuss., https://doi.org/10.5194/bg-2018-433

Manuscript under review for journal Biogeosciences

Discussion started: 19 October 2018

(c) Author(s) 2018. CC BY 4.0 License.

483 We provided another example, using isotopic data measured on a Porites core harvested in Moorea

484 (French Polynesia) (17 $30^{\prime} \mathrm{S}, 149^{\circ} 50^{\prime}$ W) (Boiseau et al., 1998). Fig. 8 illustrates the $\delta^{18} \mathrm{O}$ non-

485 linearity in time. On the left side, (Fig. 8a), seasonal measured data are compared with instrumental seawater temperature between 1980 and 1990 (Boiseau et al., 1998). On the right side, (Fig. 8b), over the last century, annual averaged measured data, originated from the same data series than seasonal data, are compared with estimated temperature in the $\left(1^{\circ}, 1^{\circ}\right)$ grid containing Moorea (Kaplan et al., 1998). The two curves are displayed to obtain the best matching. The isotopic scale of the two isotopic respectively. There is a mismatch between annual and monthly calibrations given on a unique isotopic scale.

Evidence underlined by the New Caledonia and Moorea examples must be considered following our new understanding about environmental forcing.

\subsection{Comparison of annual and monthly $\delta^{18} \mathrm{O}$ profiles}

498 The comparison between $\delta^{18} \mathrm{O}$ profiles and GISST (Parker et al., 1995) or Kaplan (Kaplan et al., 1998) 499 data sets, derived from statistical assessments, was performed over the last century. Kaplan et al. 500 (1998) compared ship-derived monthly temperature with the coral-based proxy record from Tarawa 501 atoll (Cole et al., 1993). The authors observed great discrepancy between the two curves, coral estimates being difficult to justify.

\subsubsection{Discrepancy between statistical and coral-derived temperature reconstruction}

505 4.2.1.1 Comparison of annual and monthly calibrations in New Caledonia

506 We previously displayed monthly calibrations established in New Caledonia (3.2.1 and 3.2.2). Slopes

507 (a) calculated by Stephans et al. (2004) (Table 2) are similar or higher in absolute value than the slope 
Biogeosciences Discuss., https://doi.org/10.5194/bg-2018-433

Manuscript under review for journal Biogeosciences

Discussion started: 19 October 2018

(c) Author(s) 2018. CC BY 4.0 License.

508 from $\delta^{18} \mathrm{O}$-temperature calibration utilised by Crowley et al. (1999). The slopes (a) of monthly $\delta^{18} \mathrm{O}-$

509 monthly temperature calibrations (Table 2) are strongly affected by reduced summer isotopic values corresponding to the highest temperatures, due to the light effect superimposed on the temperature effect. In contrast, the mean annual isotopic value is not affected by light because this factor varies weakly over successive years and in turn $\delta^{18} \mathrm{O}$ essentially reflects temperature. Consequently, when monthly calibration is applied to predict temperature, the seasonal $\delta^{18} \mathrm{O}$ being strongly affected by light induces negative temperature calculations, confirming the effect assessed by Crowley et al., (1999). As mentioned in Crowley et al. (1999), when the annual calibration is taken into account, the prediction of temperature over several decades becomes realistic.

We are aware that in Fig. 8, we compare two reconstructions based on different tools. However, trusting our previous conclusions that annual or monthly $\delta^{18} \mathrm{O}$ is, to a first approximation, a good temperature tracer, Fig. 8 illustrates the inconsistency between seasonal and interannual isotopic data. compared with constants from previous relationships (Fig. 7b) (Table 2). In Moorea, where mean annual temperature is $26.8^{\circ} \mathrm{C}$, value of slope (a) from monthly calibration (Fig. 9a) is of the same order as that in New Caledonia (Crowley et al., 1999). However, the slope value -0.24 derived from the annual calibration calculated over 33 years (from 1989 to 1956) (Fig. 9b) is lower than the slope calculated by Crowley et al. (1999), of -0.19 . At these sites, rainfall and in turn nebulosity is higher in

530 November-January, the period recording maximal potential irradiation and maximal temperature

531 (Boiseau et al., 1998). Despite nebulosity, irradiation affects photosynthetic activity of zooxanthellae (coral symbionts), strengthened by temperature. Since temperature and light have opposite influences

533 on $\delta^{18} \mathrm{O}$, the slope of monthly calibrations is reduced. Seasonality strongly influences intra-annual or seasonal isotopic profiles. 
Biogeosciences Discuss., https://doi.org/10.5194/bg-2018-433

Manuscript under review for journal Biogeosciences

Discussion started: 19 October 2018

(c) Author(s) 2018. CC BY 4.0 License.

535 During the last century, annual irradiation remained roughly constant. However, global warming

536 caused by progressive temperature increase is limited around the tropical belt compared to higher

537 latitudes; however this concept remains a matter of debate (Vecchi and Soden, 2007; Du and Xie,

538 2009; Zhu and Liu, 2009; Deser et al., 2010). Knowing that the weak temperature increase slightly

539 impacts photosynthetic activity (Juillet-Leclerc et al., 2014), the single temperature effect on $\delta^{18} \mathrm{O}$ is

540 weakly lower than the calculated effect neglecting light.

541 The estimation of warming during the $20^{\text {th }}$ century deduced from coral monthly calibration, is

542 estimated to be $1.2{ }^{\circ} \mathrm{C}$ (Boiseau et al., 1998), which is too high for a site located in a tropical zone,

543 whereas the trend of annual $\delta^{18} \mathrm{O}$ corresponding to $0.25{ }^{\circ} \mathrm{C}$ derived by Kaplan et al. (1998) seems

544 more realistic.

545

546 When coral $\delta^{18} \mathrm{O}$ is analysed seasonally, the isotopic profile shows a strong light effect during a year

547 while two successive years globally do not reflect light change and only weak temperature influence.

548 Therefore, interannual and monthly $\delta^{18} \mathrm{O}$-temperature calibrations for Porites, at Moorea and Amédée

549 Lighthouse are not linear. It is misleading to plot on the time scale monthly $\delta^{18} \mathrm{O}$ superimposed on

550 interannual $\delta^{18} \mathrm{O}$ because, both in French Polynesia and New Caledonia, seasonal $\delta^{18} \mathrm{O}$ variations are

551 strongly impacted by both temperature and light and annual variability is slightly influenced by light

552 and only temperature dependent. Consequently, the global warming of the $20^{\text {th }}$ century has to be

553 estimated from the annual temperature scale to remain realistic.

554

5555 Consequences for temperature reconstructions

556 From the literature dedicated to coral reconstruction based on geochemistry, several papers highlight

557 the misfit between instrumental temperature and $\delta^{18} \mathrm{O}$ (Quinn et al., 2006) and between instrumental

558 temperature and $\mathrm{Sr} / \mathrm{Ca}$ records (Alibert and McCulloch, 1997; Crowley et al., 1999, 2000; Nurhati et

559 al., 2011). Estimates of global warming during the last century as deduced by temperature

560 reconstructions seem too high for the tropical zone (Damassa et al., 2006; Gorman et al., 2012;

561 Thierney et al., 2015). A mismatch between seasonal and annual records has been recognized without 
Biogeosciences Discuss., https://doi.org/10.5194/bg-2018-433

Manuscript under review for journal Biogeosciences

Discussion started: 19 October 2018

(c) Author(s) 2018. CC BY 4.0 License.

562 any explanation proposed (Osborn et al., 2013; Abram et al., 2015). The possible influence of cloud

563 cover on proxies is suspected in a few publications (Cahyarini et al., 2014) but is it attributed to

564 precipitation or to weak photosynthesis?

565 From previous evidence arise three main concerns: $\delta^{18} \mathrm{O}$ is essentially dependent on temperature

566 according the relationships that include the lack of consistency between the influence of light on

567 monthly and annual calibrations. All reconstructions based on thermodynamic relationships, such as

568 the coupled $\mathrm{Sr} / \mathrm{Ca}-\delta^{18} \mathrm{O}$ method or the concept of pseudo-proxy induces biased conclusions. In addition, confusion between seasonal and annual calibrations causes misleading interpretations.

570

\subsection{The coupled $\mathrm{Sr} / \mathrm{Ca}-\delta^{18} \mathrm{O}$ method}

572 Pioneered investigations (McCulloh et al., 1994; Gagan et al., 1998, 2000), Ren et al. (2002) proposed

573 to deconvolve $\delta^{18} \mathrm{O}_{\text {seawater }}$ by using subseasonal coral $\delta^{18} \mathrm{O}$ and $\mathrm{Sr} / \mathrm{Ca}$. This treatment is based on the

574 oxygen thermometer (3):

$$
\delta^{18} \mathrm{O}_{\text {carbonate }}-\delta^{18} \mathrm{O}_{\text {Seawater }}=\alpha+\beta \times \operatorname{SST}\left({ }^{\circ} \mathrm{C}\right)
$$

$\alpha$ and $\beta$ being constants, and the $\mathrm{Sr} / \mathrm{Ca}$ temperature tracer following also linear relationships. The preliminary condition for applying the Ren et al. (2002) method, "Sr/Ca is solely a function of SST" may prevent any estimation (Gischler et al., 2005) or it is not respected (Wu et al., 2013), inducing spurious interpretations. Temperature values are derived from $\mathrm{Sr} / \mathrm{Ca}$ and $\delta^{18} \mathrm{O}$ calibrations assessed locally from the recent period (Mishima et al., 2010; Cahyarini et al., 2016) or from calibrations already published (Quinn et al., 2006; Nurhati et al., 2009). Then, this STT value is introduced into Eq. (3) and $\delta^{18} \mathrm{O}_{\text {seawater }}$ time series is estimated. This value may be converted into seasurface salinity (SSS) (Felis et al., 2009; Nurhati et al., 2011; Cahyarini et al., 2014).

584 The reliability of this method is discussed for multiple reasons: i) we clearly demonstrate that Eq. (3) does not include light effect, which causes vital effect; ii) $\mathrm{Sr} / \mathrm{Ca}$ calibration meaning is increasingly matter of debate (Alibert and Kinsley, 2008; Cahyarini et al., 2008; Alpert et al., 2014), and cultures

587 testing influence of light on Acropora proxies show that reliable $\mathrm{Sr} / \mathrm{Ca}$ response should be obtained 
Biogeosciences Discuss., https://doi.org/10.5194/bg-2018-433

Manuscript under review for journal Biogeosciences

Discussion started: 19 October 2018

(c) Author(s) 2018. CC BY 4.0 License.

calibrations are applied over a long time scale (more than one century), SST conditions may change at

SSS is not always possible, or oceanic advection could confuse SSS reconstruction because the relationship between $\delta^{18} \mathrm{O}_{\text {seawater }}$ and SSS is not sufficiently constrained because it is not locally estimated (Cahyarini et al., 2014; Quinn et al., 2006; Iijima et al., 2005) or may be biased by an advection (Delcroix et al., 2011).

595

Climate reconstructions based on the coupled $\mathrm{Sr} / \mathrm{Ca}-\delta^{18} \mathrm{O}$ method must be considered with a critical eye because of the constraining conditions.

\subsection{Monthly and interannual calibrations}

600 The consequences of the non-linearity between monthly and annual isotopic data are multiple. The

601 first implication is the impossibility of plotting a monthly $\delta^{18} \mathrm{O}$ curve over several decades or centuries

602 following an isotopic scale on one side and a temperature scale on the other (Quinn et al., 1998; Cobb

603 et al., 2003; Abram et al., 2015). A temperature scale deriving from monthly calibration is strongly

604 impacted by the light effect, whereas an isotopic profile based on annual variability is weakly affected

605 by light. Therefore, monthly and interannual calibrations, established from a single data series, exhibit

606 different slopes and monthly and interannual isotopic signals cannot be superimposed. Consequently,

607 global warming recorded over the $20^{\text {th }}$ century has to be quantified following the annual calibration.

608 The warming effect assessed from monthly calibration is always overestimated in terms of

609 temperature (Linsley et al., 2000; Damassa et al., 2006; Tierney et al., 2015).

610 Oceanographers are commonly face to such a concern as with salinity change not occurring on intra-

611 annual timescale but noticeable on interannual one. Thus, they commonly use 25 month Hanning filter

612 to extract the real salinity variability (Gouriou and Delcroix, 2002). From monthly $\delta^{18} \mathrm{O}$ profile

613 covering the total coral core record, it is possible to obtain interannual variability by assessing annual 
Biogeosciences Discuss., https://doi.org/10.5194/bg-2018-433

Manuscript under review for journal Biogeosciences

Discussion started: 19 October 2018

(c) Author(s) 2018. CC BY 4.0 License.

615 by removing the interannual variations. After obtaining two time series, it is necessary to statistically

616 treat each of them.

First suggested by Thomson et al. (2011), the relationship $\delta^{18} \mathrm{O}_{\text {pseudocoral }}=\mathrm{a}_{1} \times \mathrm{SST}+\mathrm{a}_{2} \times \mathrm{SSS}, \mathrm{a}_{1}$ and $\mathrm{a}_{2}$ GCM model (Linsley et al., 2017). This could be a good tool to simulate coral isotopic proxy. However, we have clearly highlighted that $\delta^{18} \mathrm{O}_{\text {seawater }}$ is included in the coral skeleton $\delta^{18} \mathrm{O}$ but $\delta 18 \mathrm{O}_{\text {seawater }}$ and SSS are not always linearly related during times such as in the case of seawater advection (Delcroix et al., 2011; Linsley et al., 2017). Knowing that the coral $\delta^{18} \mathrm{O}$ and temperature relationship is not linear, it is difficult to include the pseudo-coral concept in paleo-climatic studies (Gorman et al., 2012; Hereid et al., 2013; Osborn et al., 2013), the latter author noticing 'a mismatch between seasonal and interannual timescales'. The concept of pseudo-coral is abundantly developed in terms of theoretical reconstruction techniques (Emile-Geay et al., 2013a, 2013b; Wang et al., 2014). In order to remedy this deficiency existing in most paleo-climatic studies, Emile-Geay and Tingley (2015) proposed the use of a simple empirical transform (ITS). However, a much more efficient tool is the identification of the cause of the non-linearity. Such behaviour has been already highlighted (Felis et al., 2000; Zhang et al., 2009; Osborne et al., 2013; Abram et al., 2015; Zinke et al., 2014). (Singular Spectrum Analysis) or MTM (Multi-Taper Method)

Briefly, after capturing high- and low-frequencies present in the proxies or reconstructed noisy time series into their dominant variance patterns and MTM determines variance spectra and coherency (Vautard et al., 1992). Climatic variability so studied is the ENSO event occurring at 
Biogeosciences Discuss., https://doi.org/10.5194/bg-2018-433

Manuscript under review for journal Biogeosciences

Discussion started: 19 October 2018

(c) Author(s) 2018. CC BY 4.0 License.

642 When this method is applied to $\delta^{18} \mathrm{O}$ profile, it is difficult to separate temperature and/or salinity

643 change (Felis et al., 2000; Osborne et al., 2014; Cahyarini et al., 2014; Linsley et al., 2017) or to

644 estimate the interaction between IOD and Indian monsoon (Abram et al., 2008). The use of

645 sophisticated statistics does not always allow atmospheric and meteorological interactions to be

646 established if real proxy significance is not considered.

647

648 All the methods or concepts highlighted are used abundantly in papers dealing with the reconstruction

649 of the climate context from coral geochemical tracers; however, they do not respond to the constraints we have underlined during our demonstration.

651

\section{Conclusions}

653 By revisiting several published papers we have highlighted the role of light in $\delta^{18} \mathrm{O}$ determination,

654 light so far being an ignored vital effect. Since temperature and light influences are opposite on $\delta^{18} \mathrm{O}$,

655 it is easier to neglect light; however, this explains why synchronous $\delta^{18} \mathrm{O}$ variability observed in

656 distinct cores, even synchronous $\delta^{18} \mathrm{O}$ variability recorded on the same colony, may differ each other.

657 The WW72 data series reveal that the annual averaged measure of oxygen isotopic ratios performed

658 on several coral colonies of a single genus, collected at one site, allow comparison due to homogenous

659 light effects. This allows stronger conclusions. Interpreted with new eyes, we concluded that it is

660 likely that all coral genera $\delta^{18} \mathrm{O}$ levels are strongly temperature-dependent and should be used as

661 tracers of environmental parameters.

662 Temperature appears to be the dominant factor in $\delta^{18} \mathrm{O}$ levels because it is recorded in two ways: as a

663 thermodynamic forcing causing $\delta^{18} \mathrm{O}$ decrease, and as responsible for photosynthesis enhancement

664 inducing $\delta^{18} \mathrm{O}$ increase.

665 After observing the relationships linking the constants of annual $(\mathrm{Sr} / \mathrm{Ca})-$ temperature calibrations

666 compared to the relationships linking the constants of annual $\delta^{18} \mathrm{O}$-temperature calibrations, we

667 deduced that the analogy should be due to relative amounts of two mineral microstructures, COCs and fibres. COCs probably depend only on temperature and fibres depend on both light and temperature. 
Biogeosciences Discuss., https://doi.org/10.5194/bg-2018-433

Manuscript under review for journal Biogeosciences

Discussion started: 19 October 2018

(c) Author(s) 2018. CC BY 4.0 License.

669 Similar conclusions derive from revisited monthly $\delta^{18} \mathrm{O}$-temperature calibrations assessed for Porites

670 coral, in three sites characterised by different annual temperatures. We established a robust

671 relationship linking the constants of the respective $\delta^{18} \mathrm{O}$-temperature calibrations calculated on

672 multiple Porites colonies of different species. Taking into account all Porites $\delta^{18} \mathrm{O}-$ temperature

673 calibration constants, the high correlation coefficient obtained is at least 0.99 , underlining the

674 consistency of the calibrations. In addition, this indicates the prominent role of temperature in $\delta^{18} \mathrm{O}$

675 levels, acting both thermodynamically and through photosynthetic activity impacted by temperature.

676 We stress that the relative numbers of mineral microstructures also support this argument.

677 We explained how light impact differs according to annual or monthly time scales. Annual $\delta^{18} \mathrm{O}$

678 variations are weakly affected by annual light change while monthly variations are strongly affected

679 by seasonal light. Consequently, a $\delta^{18} \mathrm{O}$ profile derived from monthly resolution results from the

680 superposition of annual variations weakly affected by annual light change and monthly variations

681 strongly impacted by seasonal light fluctuations. When oxygen isotopes are plotted against

682 temperature, the confusion of time scales generates major misleading. For example, global warming

683 recorded over the $20^{\text {th }}$ century derived from a monthly $\delta^{18} \mathrm{O}$ profile is overestimated. 
Biogeosciences Discuss., https://doi.org/10.5194/bg-2018-433

Manuscript under review for journal Biogeosciences

Discussion started: 19 October 2018

(c) Author(s) 2018. CC BY 4.0 License.

\section{Bibliography}

686 Abram NJ, Dixon BC, Rosevear MG, Plunkett B, Gagan MK, Hantoro WS, Phipps SJ (2015),

687 Optimized coral reconstructions of the Indian Ocean Dipole: An assessment of location and 688 length considerations, Paleoceanography, 30, 1391-1405, doi:10.1002/2015PA002810.

Alibert C, Kinsley L. (2008), A 170-year Sr/Ca and Ba/Ca coral record from the western Pacific warm pool: 1. What can we learn from an unusual coral record?, J. Geophys. Res., 113, C04008, doi:10.1029/2006JC003979.

Alibert C, McCulloch MT (1997), Strontium/calcium ratios in modern Porites corals from the Great

Al-Horani FA, Ferdelman T, Al-Moghrabi SM, de Beer D (2005), Spatial distribution of calcification

Alpert AE, Cohen AL, Oppo DW, DeCarlo TM, Gove JM, Young CW (2016), Comparison of equatorial Pacific sea surface temperature variability and trends with $\mathrm{Sr} / \mathrm{Ca}$ records from multiple corals, Paleoceanography, 31, doi:10.1002/2015PA002897.

Bagnato, S., B. K. Linsley, S. S. Howe, G. M. Wellington, and J. Salinger (2005), Coral oxygen isotope records of interdecadal climate variations in the South Pacific Convergence Zone region, Geochem. Geophys. Geosyst., 6, Q06001, doi:10.1029/2004GC000879.

Barnes DJ, Lough JM (1996), Coral skeletons: storage and recovery of environmental information, Glob. Change Biol., 2, 569-582. oxygen stable isotopic composition of Porites lutea skeleton at Mururoa (French Polynesia): 
Biogeosciences Discuss., https://doi.org/10.5194/bg-2018-433

Manuscript under review for journal Biogeosciences

Discussion started: 19 October 2018

(c) Author(s) 2018. CC BY 4.0 License.

711 Bessat F and Buigues D (2001), Two centuries of variation in coral growth in a massive Porites colony from Moorea (French Polynesia) : a response of ocean-atmosphere variability from south central Pacific, Paleogeography, Paleoclimatology, Paleoecology, 175, 381-392.

Blamart D, Rollion-Bard C, Cuif JP, Juillet-Leclerc A, Lutringer A, van Weering TCE, Henriet JP (2005), C and O isotopes in deep-sea coral (Lophelia pertusa) related to skeletal microstructure, in Cold-Water Corals and Ecosystems, edited by A. Freiwald and J. M. Roberts, pp. 1005-1020, Springer, Berlin.

Boiseau M, Juillet-Leclerc A, Yiou P, Salvat B, Isdale P, Guillaume M (1998), Atmospheric and oceanic evidences of ENSO events in the south central Pacific Ocean from coral stable isotopic records over the past 137 years, Paleoceanography, 13, 671-685.

Brachert TC, Reuter M, Krüger S, Böcker A, Lohmann H, Mertz-Kraus R, Fassoulas C (2013), Density banding in corals: barcodes of past and current climate Change, Coral Reefs, 32, 10131023, DOI 10.1007/s00338-013-1056-7.

Buddemeier RW, Kinzie III RA (1976), Coral Growth, Oceanogr. Mar. Biol. Ann. Rev., 1976, 14, 183-225.

Cahyarini SY, Pfeiffer M, Timm O, Dullo WC, Schönberg (2008), Reconstructing seawater $\delta^{18}$ O from paired coral $\delta 180$ and $\mathrm{Sr} / \mathrm{Ca}$ ratios: Methods, error analysis and problems, with examples from Tahiti (French Polynesia) and Timor (Indonesia), Geochim. Cosmochim. Acta, 72, 2841-2853.

Cahyarini SY, Zinke J, Troelstra S, Suharsono, Aldrian E, Hoeksema BW (2016) Coral Sr/Ca-based sea surface temperature and air temperature variability from the inshore and offshore corals in the Seribu Islands, Indonesia, Mar.Poll.Bull., 110, 694-700.

Cardinal D, Hamelin B, Bard E, Pätzold J (2001), $\mathrm{Sr} / \mathrm{Ca}, \mathrm{U} / \mathrm{Ca}$ and $\delta^{18} \mathrm{O}$ records in recent massive 
Biogeosciences Discuss., https://doi.org/10.5194/bg-2018-433

Manuscript under review for journal Biogeosciences

Discussion started: 19 October 2018

(c) Author(s) 2018. CC BY 4.0 License.

738

739

740

741

742

743

744

745

746

747

748

749

750

751

752

753

754

755

756

757

758

759

760

761

762

763

764

765

building coral Montastraea annularis, J. Exp. Ma. Biol. Ecol., 302, 249- 260.

Cobb KM, Charles CD, ChengH, Edwards RL (2003) El Niño/Southern Oscillation and tropical Pacific climate during the last Millennium, Nature, 424, 271- 276.

Cohen AL, Layne GD, Hart SR, Lobel PS (2001), Kinetic control of skeletal Sr/Ca in a symbiotic coral: implications for the paleotemperature proxy. Paleoceanography 16 (1), 20-26.

Cole JE and Fairbanks RG (1990), The Southern Oscillation recorded in the $\delta^{18} \mathrm{O}$ of corals from Tarawa Atoll, Paleoceanography, 5, 669-683.

Cole JE, Fairbanks RG, and Shen GT (1993), Recent variability in the Southern Oscillation: Isotopic results from a Tarawa Atoll coral, Science, 260, 1790-1793.

Cooper TM, De'ath G, Fabricius KE, Lough JM (2008), Declining coral calcification in massive Porites in two nearshore regions of the northern Great Barrier Reef Global Change Biology 14, 529-538, doi: 10.1111/j.1365-2486.2007.01520.

Crowley TJ, Quinn TM, Hyde TM (1999) Validation of coral temperature calibrations, Paleoceanography, 14, 605-615.

Cuif JP, Dauphin Y, (1998), Microstructural and physico-chemical characterisation of centres of calcification in septa of some Scleractinian corals. Pal Zeit 72:257-270.

Damassa TD, Cole JE, Barnett HR, Ault TR, McClanahan TR (2006), Enhanced multidecadal climate variability in the seventeenth century from coral isotope records in the western Indian Ocean, Paleoceanography, 21, PA2016, doi:10.1029/2005PA001217.

Delcroix T,.Alory G, Cravatte S, Corrège T, McPhadenMJ (2011), A gridded sea surface salinity data set for the tropical Pacific with sample applications (1950-2008), Deep- Sea Res.I, 58, 38-48.

DeLong KL, Quinn TM, Taylor FW, Shen CC, Lin K (2013), Improving coral-base paleoclimate reconstructions by replicating 350 years of coral $\mathrm{Sr} / \mathrm{Ca}$ variations, Palaeogeog., Palaeoclim., Palaeoecol., 373, 6-24.

Deng W, Wei G, McCulloch M, Xie L, Liu Y, Zeng T (2014), Evaluation of annual resolution coral geochemical records as climate proxies in the Great Barrier Reef of Australia, Coral Reefs, 33, 965-977, DOI 10.1007/s00338-014-1203-9.

Deser C, Phillips AS, Alexander MA (2010), Twentieth century tropical sea surface temperature 
Biogeosciences Discuss., https://doi.org/10.5194/bg-2018-433

Manuscript under review for journal Biogeosciences

Discussion started: 19 October 2018

(c) Author(s) 2018. CC BY 4.0 License.

766

767

768

769

770

771

772

773

774

775

776

777

778

779

780

781

782

783

784

785

786

787

788

789

790

trends revisited, Geophys. Res. Lett., 37, L10701, doi:10.1029/2010GL043321.

D’Olivo J.P., Sinclair D.J., Rankenburg K., McCulloch M.T. (2018) A universal multi-trace element calibration for reconstructing sea surface temperatures from long-lived Porites corals: Removing ‘vital-effects'. Geochim. Cosmochim. Acta 239, 109-135.

Du Y, Xie SP (2008), Role of atmospheric adjustments in the tropical Indian Ocean warming during the 20th century in climate models, Geophys. Res. Lett., 35, L08712, doi:10.1029 /2008GL033631.

Emile-Geay J, Cobb KM, Mann ME, Wittenberg AT (2013a) Estimating Central Equatorial Pacific SST Variability over the Past Millennium. Part I: Methodology and Validation, J. Clim., 26, $2302-2328$

Emile-Geay J, Cobb KM, Mann ME, Wittenberg AT (2013b) Estimating Central Equatorial Pacific SST Variability over the Past Millennium. Part II: Reconstructions and Implications, J. Clim., $26,23292352$.

Emile-Geay J, Tingley M (2015), Inferring climate variability from nonlinear proxies: application to palaeo-ENSO studies, Clim. Past, 12, 31-50, www.clim-past.net/12/31/2016/ doi:10.5194/cp$12-31$.

Epstein S, Buchsbaum R, Lowenstam H, Urey HC (1951), carbonate water isotopic temperature scale, Bull. Geol. Soc. Am., v. 62, p. 417.

Epstein S, Buchsbaum R, Lowenstam H, Urey HC (1953), Revised carbonate-water isotopic temperature scale, Bull. Geol. Soc. Am., 62,417-425.

Fairbanks RG, Evans MN, Rubenstone1 JL, Mortlock RA, Broad K, Moore MD, CharlesCD (1997) Evaluating climate indices and their geochemical proxies measured in corals, Coral Reefs , 16, Suppl.: S93-S100.

Fairbanks RG, Dodge RE (1979) Annual periodicity of the ${ }^{18} \mathrm{O} /{ }^{16} \mathrm{O}$ and ${ }^{13} \mathrm{C} /{ }^{12} \mathrm{C}$ ratios in the coral Montastrea annularis, Geochim. Cosmochim. Acta, 43, 1009-1020.

Felis T, Pätzold J, Loya Y, Fine M, Nawar NJ, Wefer G (2000), A coral oxygen isotope record from the northern Red Sea documenting NAO, ENSO and North Pacific teleconnections on Middle East climate variability since the year 1750, Paleoceanography, 15, 679-694. 
Biogeosciences Discuss., https://doi.org/10.5194/bg-2018-433

Manuscript under review for journal Biogeosciences

Discussion started: 19 October 2018

(c) Author(s) 2018. CC BY 4.0 License.

794

795

796

797

798

799

800

801

802

803

804

805

806

807

808

809

810

811

812

813

814

815

816

817

818

819

820

Felis T, Pätzold J, Loya, Y (2003) Mean oxygen-isotope signatures in Porites sp. corals: inter-colony variability and correction for extension-rate effects, Coral Reefs 22, 328-336,DOI $10.1007 / \mathrm{s} 00338-003-0324-3$

Felis1 T, Suzuki A, Kuhnert H, Dima M, Lohmann G, Kawahata H (2009), Subtropical coral reveals abrupt early-twentieth-century freshening in the western North Pacific Ocean, Geology, 37, 527-530.

Gagan MK, Ayliffe LK, Hopley D, Cali JA, Mortimer GE, Chappell J, McCulloch MT, Head, M.J., (1998), Temperature and surface-ocean water balance of the mid-Holocene tropical western Pacific, Science, 279, 1014-1018.

Gagan MK, Ayliffe LK, Beck JW, Cole JE, Druffel ERM, Dunbar RB, Shrag DP (2000), New views of tropical paleoclimates from corals, Quatern. Sc. Rev., 19, 45-64.

Gagan, MK, Dunbar GB, Suzuki A (2012), The effect of skeletal mass accumulation in Porites on coral $\mathrm{Sr} / \mathrm{Ca}$ and $\delta^{18} \mathrm{O}$ paleothermometry, Paleoceanography, 27, PA1203, doi:10.1029/2011PA002215

Gattuso JP, Allemand D, Frankignoulle M (1999), Photosynthesis and calcification at cellular, organismal and community levels in coral reefs: a review on interactions and control by carbonate chemistry, Amer. Zool, 39, 160-183.

Gischler E, Oschmann W (2005) Historical Climate Variation in Belize (Central America) as Recorded in Scleractinian Coral Skeletons, Palaios, 20, 159-174.

Gladfelter EH (1982), Skeletal development in Acropora cervicornis: I. Patterns of calcium carbonate accretion in the axial corallite, Coral Reefs, $1,45-51$.

Gladfelter EH (1984), Skeletal development in Acropora cervicornis: III. A comparison of monthly rates of linear extension and Calcium Carbonate accretion measured over a year, Coral Reefs, 3, $51-57$

Goodkin NF, Hughen KA, Cohen AL, Smith SR (2005), Record of Little Ice Age sea surface temperatures at Bermuda using a growth-dependent calibration of coral $\mathrm{Sr} / \mathrm{Ca}$, Paleoceanography, 20, PA4016, doi:10.1029/2005PA001140. 
Biogeosciences Discuss., https://doi.org/10.5194/bg-2018-433

Manuscript under review for journal Biogeosciences

Discussion started: 19 October 2018

(c) Author(s) 2018. CC BY 4.0 License.

821 Goreau TF (1959), The physiology of skeleton formation in coral I: a method for measuring the rate of calcium deposition under different light conditions, Biol. Bull., 116, 59-75.

823 Gorman, MK, Quinn TM, Taylor FG, Partin JW, Cabioch G, Austin Jr. JA, Pelletier B, Ballu V, Maes C, Saustrup S (2012), A coral-based reconstruction of sea surface salinity at Sabine Bank, Vanuatu from 1842 to 2007 CE, Paleoceanography, 27, PA3226, doi:10.1029/2012PA002302.

Gouriou Y, and Delcroix T (2002), Seasonal and ENSO variations of sea surface salinity and temperature in the South Pacific Convergence Zone during 1976-2000, J. Geophys. Res., 107(C12), 8011, doi:10.1029/2001JC000830.

Hereid KA, Quinn TM, Okumura YM (2013), Assessing spatial variability in El Niño-Southern Oscillation event detection skill using coral geochemistry, Paleoceanography, 28, 14-23, doi:10.1029/2012PA002352.

Hughes MK, Ammann CM (2009), The future of the past—an earth system framework for high resolution paleoclimatology: editorial essay, Clim. Change, 94, 247-259, DOI 10.1007/s10584009-9588-0.

Iijima H, Kayanne H, Morimoto M, Abe O (2005), Interannual sea surface salinity changes in the western Pacific from 1954 to 2000 based on coral isotope analysis, Geophys. Res. Lett., 32, L04608, doi:10.1029/2004GL022026.

Iluz D, Dubinski D (2015), Coral photobiology : new light on old views. Zoology 118, 71-78.

Jell JS (1974), The microstructure of some scleractinian corals. Proc Second Intl Coral Reef Symp. Austr 2:301-320.

Jokiel PL, Coles SL (1977), Effects of temperature on the mortality and growth of Hawaiian reef corals. Mar. Biol. 43, 201-208.

Juillet-Leclerc A, Schmidt G (2001), A calibration of the oxygen isotope paleothermometer of coral aragonite from Porites, Geophysical Research Letter, 28, 4135-4138, 2001. 
Biogeosciences Discuss., https://doi.org/10.5194/bg-2018-433

Manuscript under review for journal Biogeosciences

Discussion started: 19 October 2018

(c) Author(s) 2018. CC BY 4.0 License.

848

Juillet-Leclerc A, Reynaud S, Rollion-Bard C, Cuif JP, Dauphin Y, Blamart D, Ferrier-Pagès C, Allemand D (2009), Oxygen isotopic signature of the skeletal microstructures in cultured corals: identification of vital effects. Geochim. Cosmochim. Acta 73, 5320-5332.

Juillet-Leclerc A, Reynaud S (2010), Light effects on the isotopic fractionation of skeletal oxygen and carbon in the cultured zooxanthellate coral, Acropora: implications for coral-growth rates. Biogeosciences 7, 893-906.

Juillet-Leclerc A, Reynaud S, Dissard D, Tisserand G, Ferrier-Pagès C (2014), Light is an active contributor to vital effects of coral skeleton proxies. Geochim. Cosmochim. Acta 140, 671-690.

Juillet-Leclerc A, Rollion-Bard C, Reynaud S, Ferrier-Pagès C (2018), A new paradigm for $\delta 18 \mathrm{O}$ in coral skeleton oxygen isotope fractionation response to biological kinetic effects, Chem. Geol., $483,131-140$.

Karako-Lampert S, Katcoff DJ, Achituv Y, Dubinski Z, Stambler N (2004), Response of Symbiodinium microadriaticum clade B to different environmental conditions. J. Exp. Mar. Bio. Ecol. 318, 31-38.

Kaplan A, Cane M, Kusnir Y, Blumenthal B, Rajagopalan B (1998), Analyses of global Sea Surface Temperature 1856-1991, Journal of Geophysical Research, 103, 18567-18589.

Kim ST, O'Neil JR, Hilaire-Marcel C, Mucci A (2007), Oxygen isotope fractionation between synthetic aragonite and water. Influence of temperature and $\mathrm{Mg}^{2+}$ concentration. Geochim. Cosmochim. Acta 71, 4704-4715.

Kühl M, Cohen Y, Dansgaard T, Jorgensen BB, Revsbech NP (1995), Microenvironmental and photosynthesis in scleractininan corals studied with microsensors for $\mathrm{O}_{2}, \mathrm{pH}$ and light. Marine Ecology Progress Series 117, 159-172.

Land LS, Lang JC, Barnes DJ (1975), Extension rate: a primary control on the isotopic composition of west Indian (Jamaican) scleractinian reef coral skeletons, Mar. Biol. 33, 221-233.

Le Bec N, Juillet-Leclerc A, Correge T, Blamart D, Delcroix T (2000), A coral $\delta^{18}$ O record of ENSO driven sea surface salinity in Fiji (south-western tropical Pacific), Geophys. Res. Lett. 27, 38973900. 
Biogeosciences Discuss., https://doi.org/10.5194/bg-2018-433

Manuscript under review for journal Biogeosciences

Discussion started: 19 October 2018

(c) Author(s) 2018. CC BY 4.0 License.

875

876

877

878

879

880

881

882

883

884

885

886

887

888

889

890

891

892

893

894

895

896

897

898

899

900

901

Linsley BK, Messier RG, Dunbar RB (1999), Assessing between-colony oxygen isotope variability in the coral Porites lobata at Clipperton Atoll, Coral Reefs, 18, 13-27.

Linsley BK, Wellington GM, Schrag GM (2000), Decadal Sea Surface Temperature Variability in the Subtropical South Pacific from 1726 to 1997 A.D. Science 290, 1145-1148.

Linsley BK, Wellington GM, Schrag DP, Ren L, Salinger MJ, and Tudhope AW (2004), Geochemical evidence from corals for changes in the amplitude and spatial pattern of South Pacific interdecadal climate variability over the last 300 years, Clim. Dyn., 22, 1-11, doi:10.1007/ $50038200-0364-y$.

Linsley BK, Kaplan A, Gouriou Y, Salinger J, deMenocal PB, Wellinton GM, Howe SS (2006), Tracking the extent of the South Pacific Convergence Zone since the early 1600s, Geochem., Geophys. Geosys. 7 doi:10.1029/2005GC001115.

Linsley,B K, Wu HC, Rixen T, Charles CD, \$ Gordon AL, Moore MD (2017), SPCZ zonal events and downstream influence on surface ocean conditions in the Indonesian Throughflow region, Geophys. Res. Lett., 44, 293-303, doi:10.1002/2016GL070985.

Liu Y, Peng Z, Shen CC, Zhou R, Song S, Shi Z, Chen T, Wei G, DeLong KL (2013), Recent 121 year variability of western boundary upwelling in the northern South China Sea, Geophys. Res. Lett., 40, 3180-3183, doi:10.1002/grl.50381.

Lough JM, Barnes DJ (2000), Environmental control on growth of the massive coral Porites, J. Exp. Mar. Biol. Ecol., 245, 225-43.

Lough, JM (2008), Shifting climate zones for Australia's tropical marine ecosystems, Geophys. Res. Lett., 35, L14708, doi:10.1029/2008GL034634.

Lough JM, Cooper TF (2011), New insights from coral growth band studies in an era of rapid environmental change, Earth-Science Reviews, 108, 170-184.

Lough JM, Cantin NE (2014), Perspectives on Massive Coral Growth Rates in a Changing Ocean, Biol. Bull. 226: 187-202.

Lowenstam HA, Weiner S (1989), On Biomineralization. Oxford University Press, New York p 207251. 
Biogeosciences Discuss., https://doi.org/10.5194/bg-2018-433

Manuscript under review for journal Biogeosciences

Discussion started: 19 October 2018

(c) Author(s) 2018. CC BY 4.0 License.

902 McConnaughey TA (1989), C-13 and O-18 isotopic desequilibrium in biological carbonates: I.

903 Patterns. Geochim. Cosmochim. Acta 53, 151-162.

904 McCulloch, MT, Gagan MK, Mortimer GE, Chivas AR, Isdale PJ (1994), A high-resolution Sr/Ca and

$905 \delta^{18} \mathrm{O}$ coral record from the Great Barrier Reef, Australia, and the 1982-1983 El Niño, Geochim.

906 Cosmochim. Acta, 5c8, 2747-2754.

907 Maier C, Felis T, Pätzold J, Bak RPM (2004), Effect of skeletal growth and lack of species effects in

908 the skeletal oxygen isotope climate signal within the coral genus Porites, Marine Geology, 207,

$909 \quad 193-208$.

910 Marshall JF, McCulloch MT (2002), An assessment of the Sr/Ca ratio on shallow water hermatypic 911 corals as a proxy for sea surface temperature. Geochim. Cosmochim. Acta 66, 3263-3280.

912 Marshall AT, Clode P (2004), Calcification rate and the effect of temperature in a zooxanthellate and 913 an azooxanthellate scleractinian reef coral, Coral Reefs 23, 218-224, DOI 10.1007/s00338-004$914 \quad 0369-\mathrm{y}$

915 Meibom A, Yurimoto H, Cuif JP, Domart-Coulon I, Houlbrèque F, Constantz B, Dauphin Y, 916 Tambutté E, Tambutté S, Allemand D, Wooden J, Dunbar R, (2006), Vital effect in coral 917 skeletal composition display strict three-dimensional control, Geophys. Res. Let. 30, doi:10, $918 \quad 1029 / 2006$ GL025968.

919 Mishima M, Suzuki A, Nagao M, Ishimura T, Inoue M, Kawahata H (2010), Abrupt shift toward 920 cooler condition in the earliest 20th century detected in a 165 year coral record from Ishigaki

Nothdurft LD, Webb GE (2007), Microstructure of common reef-building coral genera Acropora, Pocillopora, Goniastrea and Porites: constraints on spatial resolution in geochemical sampling, Facies, 53, 1-26.

Nurhati, I. S., K. M. Cobb, C. D. Charles, and R. B. Dunbar (2009), Late 20th century warming and freshening in the central tropical Pacific, Geophys. Res. Lett., 36, L21606, doi:10.1029/2009GL040270.

Nurhati I.S., Cobb K.M. and Di Lorenzo E. (2011) Decadal-Scale SST and Salinity Variations in the Central Tropical Pacific: Signatures of natural and anthropogenic climate change, J. Clim. 24, 
Biogeosciences Discuss., https://doi.org/10.5194/bg-2018-433

Manuscript under review for journal Biogeosciences

Discussion started: 19 October 2018

(c) Author(s) 2018. CC BY 4.0 License.

3294-3308, DOI: 10.1175/2011JCLI3852.

Osborne MC, Dunbar RB, Mucciarone DA, Sanchez-Cabeza JA, Druffel H (2013), Regional calibration of coral-based climate reconstructions from Palau, West Pacific Warm Pool (WPWP), Palaeogeog. Palaeoclim. Palaeoecol., 386, 308-320.

Osborne MC, Dunbar RB, Mucciarone DA, Druffel H, Sanchez-Cabeza JA (2014), A 215-yr coral $\delta^{18} \mathrm{O}$ time series from Palau records dynamics of the West Pacific Warm Pool following the end of the Little Ice Age, Coral Reefs, 33, 719-731 DOI 10.1007/s00338-014-1146-1.

Parker DE, Folland CK, Jackson M (1995), Marine surface temperature: observed variations and data requirements, Clim. Change, 31, 559-600.

Porter JW, Muscatine L, Dubinski Z, Falkowski PG (1984), Primary production and photoadaptation in light- and shade-adapted colonies of the symbiotic corals Stylophora pistillata, Proc. R. Soc. Lond. B 222, 161-180.

Quinn TM, Crowley TJ, Taylor FW, Hénin C, Joannot P, Join Y (1998), A multicentury isotope record from a New Caledonia coral: interannual and decadal sea surface temperature variability in the southwest Pacific since 1657 A.D., Paleoceanography, 13, 412-426.

Quinn TM, Sampson DE (2002), A multiproxy approach to reconstructing sea surface conditions using coral skeleton geochemistry, Paleoceanography, 17, 1062, doi:10.1029/2000PA000528.

Quinn,TM, Taylor FW, Crowley TJ (2006), Coral-based climate variability in the Western Pacific Warm Pool since 1867, J. Geophys. Res., 111, C11006, doi:10.1029/2005JC003243.

Ren L, Linsley BK, Wellington GM, Schrag DP, Hoegh-Guldberg O (2003), Deconvolving the $\delta^{18} \mathrm{O}$ seawater component from subseasonal coral $\delta^{18} \mathrm{O}$ and $\mathrm{Sr} / \mathrm{Ca}$ at Rarotonga in the southwestern subtropical Pacific for the period 1726 to 1997, Geochim. Cosmochim. Acta, 67, 1609-1621. 
Biogeosciences Discuss., https://doi.org/10.5194/bg-2018-433

Manuscript under review for journal Biogeosciences

Discussion started: 19 October 2018

(c) Author(s) 2018. CC BY 4.0 License.

955 Reynaud-Vaganay S, Ferrier-Pagès C, Sambrotto R, Juillet-Leclerc A, Jaubert J, Gattuso JP (2002), A

956 novel culture technique for scleractinian corals: application to investigate changes in skeletal $\delta^{18} \mathrm{O}$ as a function of temperature, Mar. Ecol. Prog. Series, Vol. 238: 81-89.

Reynolds RW, Smith TM (1994), Improved global sea surface temperature analysis using optimum interpolation, J. Clim, 7, 929-948.

Rollion-Bard C, Chaussidon M, France-Lanord C (2003), pH control on oxygen isotopic composition of symbiotic corals, Earth and Planetary Science Review, 215, 265-273.

962 Stephans CL, Quinn TM, Taylor FW and Corrège T (2004) Assessing the reproducibility of coralbased climate records, Geophys. Res. Lett., 31, L18210, doi:10.1029/2004GL020343.

Stolarski J (2003), Three-dimensional micro- and nanostructural characteristicsof the scleractinian coral skeleton: a biocalcification proxy, Acta Palaeontol Polonica, 48, 497-530.

Su H, Jiang JH, Vane DG, Stephens GL(2008), Observed vertical structure of tropical oceanic clouds sorted in large-scale regimes, Geophys. Res. Lett., 35, L24704, doi:10.1029/2008GL035888.

Thompson, D. M., T. R. Ault, M. N. Evans, J. E. Cole, and J. Emile-Geay (2011), Comparison of observed and simulated tropical climate trends using a forward model of coral $\delta^{18} \mathrm{O}$, Geophys. Res. Lett., 38, L14706, doi:10.1029/2011GL048224.

Tierney, JE, Abram NJ, Anchukaitis KJ, Evans MN, Giry C, Kilbourne KH, Saenger CP, Wu HC, ZinkeJ (2015), Tropical sea surface temperatures for the past four centuries reconstructed from coral archives, Paleoceanography, 30, doi:10.1002/2014PA002717.

Tudhope AW, Shimmield GB, Chilcott CP, Jebb M, Fallick AE, Dalgleish AN (1995), Recent

978 Urey HC, Thermodynamic properties of isotopic substances, Jour. Chem. Soc., 562-581, 1947.

Urey HC, Lowenstam HA, Epstein S, McKinney CR (1951), Measurements of paleotherperature of the upper cretaceous of England, Denmark, and the Southeastern United States, Bull. Geol. Soc. Am., 62, 399-416.

981 Vautard R, Yiou P, Ghil M (1992), Singular-spectrum analysis: A toolkit for short, noisy chaotic 
Biogeosciences Discuss., https://doi.org/10.5194/bg-2018-433

Manuscript under review for journal Biogeosciences

Discussion started: 19 October 2018

(c) Author(s) 2018. CC BY 4.0 License.

982

983

984

985

986

987

988

989

990

991

992

993

994

995

996

997

998

999

1000

1001

1002

1003

1004

1005

1006

1007

1008

1009

signals, Phys. D, 58, 95-126.

Vecchi GA, Soden BJ (2007), Global Warming and the Weakening of the Tropical Circulation, J. Clim. 20, 4316-4340, DOI: 10.1175/JCLI4258.1.

Von Euw S, Zhang Q, Manichev V, Murali N, Gross J, Feldman LC, Gustafsson T, Flach C, Mendelsohn R, Falkowskil PG (2017), Biological control of aragonite formation in stony corals, Science 356, 933-938.

Wang J, Emile-Geay J, Guillot D, Smerdon JE, Rajaratnam B (2014), Evaluating climate field reconstruction techniques using improved emulations of real-world conditions, Clim. Past, 10, $1-19$.

Watanabe T, Gagan MK, Corrège T, Scott-Gagan H, Cowley J, Hantoro W (2003), Oxygen isotope systematics in Diploastrea heliopora: New coral archive of tropical paleoclimate, Geochim. Cosmochim. Acta, Vol. 67, No. 7, pp. 1349-1358.

Weber JN, Woodhead PMJ (1971), Diurnal variations in the isotopic composition of dissolved inorganic carbon in seawater from coral reef environmens, Geochim. Cosmochim. Acta, 35, $891-902$.

Weber JN, Woodhead PMJ (1972), Temperature dependence of Oxygen-18 concentration in reef coral carbonates, J. Geophys. Res., 77, 463-473.

Wei G, Deng W, Yu K, Li X, Sun W, Zhao J (2007), Sea surface temperature records in the northern South China Sea from mid-Holocene coral Sr/Ca ratios, Paleoceanography, 22, PA3206, doi:10.1029/2006PA001270.

Worum FP, Carricart-Ganivat JP, Besnon L, Golicher D (2007), Simulation and observations of annual density banding in skeleton of Montrastraea (Cnidaria: Scleractinia) growing under thermal stress associated with ocean warming, Limn. Oceanogr., 52, 2317-2323.

Wu HC, Linsley BK, Dassié EP, Schiraldi Jr. B, deMenocal BP (2013), Oceanographic variability in the South Pacific Convergence Zone region over the last 210 years from multi-site coral $\mathrm{Sr} / \mathrm{Ca}$ records, Geochem. Geophys. Geosyst., 14, 1435-1453, doi:10.1029/2012GC004293.

Zhang L, Chang P, Tippett MK (2009), Linking the Pacific Meridional Mode to ENSO: Utilization of a Noise Filter, J. Clim., 22, 905-921, DOI: 10.1175/2008JCLI2474.1. 
Biogeosciences Discuss., https://doi.org/10.5194/bg-2018-433

Manuscript under review for journal Biogeosciences

Discussion started: 19 October 2018

(c) Author(s) 2018. CC BY 4.0 License.

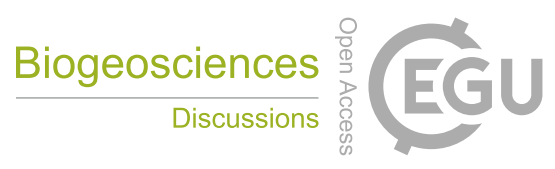

(c) (i)

1010 Zinke J, Rountrey A, Feng M, Xie SP, Dissard D, Rankenburg K, Lough JM, McCulloch MT (2014),

1011 Corals record long-term Leeuwin current variability including Ningaloo Niño/Niña since 1795,

$1012 \quad$ Nature Com., DOI: 10.1038/ncomms4607.

1013 Zhu X, Liu Z (2009), Tropical SST Response to Global Warming in the Twentieth Century, J. Cim.,

$1014 \quad 22,1305-1312$, DOI: $10.1175 / 2008 J C L I 2164.1$.

1015

1016 
Biogeosciences Discuss., https://doi.org/10.5194/bg-2018-433

Manuscript under review for journal Biogeosciences

Discussion started: 19 October 2018

(c) Author(s) 2018. CC BY 4.0 License.

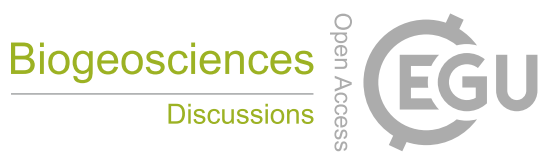

(c) (i)

40

\section{Table Captions}

1018

1019 Table 1 - Groups of coral genera from WW72, identified as showing $\delta^{18} \mathrm{O}-$ temperature calibration

1020 constants linearly linked with correlation coefficient $R^{2} \geq 0.99$ (Fig. 3). They have been first

1021 highlighted by calibrations forming bundle characterized by intersections defining $\delta^{18} \mathrm{O}$ and

1022 temperature ranges (Fig. 1d).

1023

1024 Table 2 - Values of constant of $\delta^{18} \mathrm{O}$-temperature calibrations from WW72, and from New

1025 Caledonia (Stephans et al., 2004), Clipperon (Linsley et al., 1999) and Indonesia (Maier et al., 2004).

1026

1027 
Biogeosciences Discuss., https://doi.org/10.5194/bg-2018-433

Manuscript under review for journal Biogeosciences

Discussion started: 19 October 2018

(c) Author(s) 2018. CC BY 4.0 License.

\section{Figure Captions}

1029

1030 Figure 1 - Figures of the revisited Weber and Woodhead (1972) data series. Fig. 1a is the location of 1031 all the islands considered by the authors determining temperatures. Fig. 1b displays calibrations 1032 annual temperature-annual $\delta^{18} \mathrm{O}$, plotted by considering annual temperature as the unknown 1033 parameters. Fig. 1c displays annual $\delta^{18} \mathrm{O}$-annual temperature calibrations plotted with annual coral $1034 \delta^{18} \mathrm{O}$ as the unknown parameter, annual temperature being the robust parameter. Fig. 1d displays 1035 bundles of annual $\delta^{18} \mathrm{O}$-annual temperature calibrations as we identify them from Fig. 1c, for the 1036 groups including Porites and Acropora. From Fig. 1d, it is possible to generate annual temperature 1037 and annual $\delta^{18} \mathrm{O}$ ranges corresponding to the intersection of the calibrations. This feature is made 1038 possible by the homogenous light influence on calibrations.

1039

1040 Figure 2 - Annual $\left(\delta^{18} \mathrm{O}_{\text {coral }}-\delta^{18} \mathrm{O}_{\text {seawater }}\right)$-annual temperature calibrations. Weber and Woohead 1041 (1972) data series provided coral data. $\delta^{18} \mathrm{O}_{\text {seawater }}$ are introduced in the annual $\delta^{18} \mathrm{O}$-annual temperature 1042 calibrations according to Juillet-Leclerc and Schmidt (2001) method. Some genera are not present in 1043 all the sites, in turn at all temperatures and only corresponding $\delta^{18} \mathrm{O}_{\text {seawater }}$ are introduced.

Acropora $\quad \delta^{18} \mathrm{O}_{\text {carbonate }}-\delta^{18} \mathrm{O}_{\text {Seawater }}=-0.21 \times \operatorname{SST}\left({ }^{\circ} \mathrm{C}\right)+1.26, \mathrm{R}^{2}=0.87, \mathrm{n}=24, \mathrm{p}<0.001$

Porites $\quad \delta^{18} \mathrm{O}_{\text {carbonate }}-\delta^{18} \mathrm{O}_{\text {Seawater }}=-0.20 \times \operatorname{SST}\left({ }^{\circ} \mathrm{C}\right)+0.45, \mathrm{R}^{2}=0.83, \mathrm{n}=22, \mathrm{p}<0.001$

Montipora $\quad \delta^{18} \mathrm{O}_{\text {carbonate }}-\delta^{18} \mathrm{O}_{\text {seawater }}=-0.19 \times \operatorname{SST}\left({ }^{\circ} \mathrm{C}\right)+0.64, \mathrm{R}^{2}=0.64, \mathrm{n}=12, \mathrm{p}<0.05$

Platygira $\quad \delta^{18} \mathrm{O}_{\text {carbonate }}-\delta^{18} \mathrm{O}_{\text {seawater }}=-0.19 \times \operatorname{SST}\left({ }^{\circ} \mathrm{C}\right)-0.08, \mathrm{R}^{2}=0.93, \mathrm{n}=11, \mathrm{p}<0.001$

Pavona $\quad \delta^{18} \mathrm{O}_{\text {carbonate }}-\delta^{18} \mathrm{O}_{\text {seawater }}=-0.17 \times \operatorname{SST}\left({ }^{\circ} \mathrm{C}\right)-0.47, \mathrm{R}^{2}=0.87, \mathrm{n}=8, \mathrm{p}<0.01$

Discrepancies between the different genera calibrations are related to microstructure distribution characterizing each morphology.

1052 Figure 3 - Linear relationship between (b) and (a), constants of the annual $\delta^{18} \mathrm{O}$-annual temperature 
Biogeosciences Discuss., https://doi.org/10.5194/bg-2018-433

Manuscript under review for journal Biogeosciences

Discussion started: 19 October 2018

(c) Author(s) 2018. CC BY 4.0 License.

1054

1055

1056

1057

1058

1059

1060

1061

1062

1063

1064

1065

1066

1067

1068

1069

1070

1071

1072

1073

1074

1075

1076

1077

1078

1079

1080

data. Fig. 3a displays constants values from the 44 coral genera of Table 1. (a) is considered as the disequilibrium indicator compared to -0.19 , the slope value derived from the theoretical $\delta^{18} \mathrm{O}-$ temperature relationship at equilibrium (Kim et al., 2007). The relationship $\mathrm{b}=-29.07 \mathrm{x} a-5.13, \mathrm{R}^{2}=$ $0.95, \mathrm{n}=44, \mathrm{p}<0.001$ (the green line) takes into account all the data (dark green diamonds), whereas $\mathrm{b}$ $=-27.94 \times \mathrm{a}-4.84, \mathrm{R}^{2}=0.90, \mathrm{n}=40, \mathrm{p}<0.001$ (the blue line) is assessed without the 4 extreme data (the remaining data are the blue crosses). On Fig. 3b, the dots are similar to the dots displayed on Fig. 3a, however, color of the dots corresponds to the color of the calibration bundles of Fig. 1c.

Group I $\quad \mathrm{b}=-24.43 \times \mathrm{a}-4.18, \mathrm{R}^{2}=0.99, \mathrm{n}=9, \mathrm{p}<0.001$ (the orange line)

Group II $\quad \mathrm{b}=-26.63 \times \mathrm{a}-4.91, \mathrm{R}^{2}=0.99, \mathrm{n}=8, \mathrm{p}<0.001$ (the violin line)

Group III $\quad \mathrm{b}=-25.85 \times \mathrm{a}-4.10, \mathrm{R}^{2}=0.99, \mathrm{n}=7, \mathrm{p}<0.001$ (the blue line)

Acropora Group IV $\mathrm{b}=-25.60 \times \mathrm{a}-3.79, \mathrm{R}^{2}=0.99, \mathrm{n}=10, \mathrm{p}<0.001$ (the green line)

Porites Group V $\quad \mathrm{b}=-28.40 \times \mathrm{a}-5.16, \mathrm{R}^{2}=0.999, \mathrm{n}=9, \mathrm{p}<0.001$ (the brown line)

$\mathrm{T}_{\text {intersection }}$ and $\delta_{\text {intersection }}$ are only given for Acropora and Porites groups.

Correlation coefficient of all the linear relationships are very high. All genera included in each group share identical microstructure distribution due to common feature of morphology.

Figure 4 -Graphs derived from Stephans et al. (2004) data, available on NOAA (National Climatic Data Center site) (https://www.ncdc.noaa.gov/paleo/study/1877). On Fig. 4a are reported seasonal isotopic profiles from 1967 to 1993 period for 92PAC coral core (blue curve), 92PAD coral core (pink curve), 99PAA coral core (green curve) and 92PAA coral core (violin curve). All the cores have been harvested at Fort Amédée lighthouse proximity. Seasonal isotopic profiles are strongly impacted by seasonality with different light influence. Fig. $4 \mathbf{b}$ displays seasonal $\delta^{18} \mathrm{O}$-seasonal temperature (GISS SST) calibrations for the coral cores studied.

92PAC $\delta^{18} \mathrm{O}_{\text {carbonate }}=-0.17 \times \operatorname{SST}\left({ }^{\circ} \mathrm{C}\right)-0.08, \mathrm{R}^{2}=0.77, \mathrm{n}=296, \mathrm{p}<0.001$, blue curve

99PAA $\delta^{18} \mathrm{O}_{\text {carbonate }}=-0.16 \times \operatorname{SST}\left({ }^{\circ} \mathrm{C}\right)-0.39, \mathrm{R}^{2}=0.67, \mathrm{n}=296, \mathrm{p}<0.001$, green curve

92PAC $\delta^{18} \mathrm{O}_{\text {carbonate }}=-0.15 \times \operatorname{SST}\left({ }^{\circ} \mathrm{C}\right)-0.62, \mathrm{R}^{2}=0.62, \mathrm{n}=296, \mathrm{p}<0.001$, violin curve

92PAD $\delta^{18} \mathrm{O}_{\text {carbonate }}=-0.14 \times \operatorname{SST}\left({ }^{\circ} \mathrm{C}\right)-1.09, \mathrm{R}^{2}=0.59, \mathrm{n}=296, \mathrm{p}<0.001$, pink curve 
Biogeosciences Discuss., https://doi.org/10.5194/bg-2018-433

Manuscript under review for journal Biogeosciences

Discussion started: 19 October 2018

(c) Author(s) 2018. CC BY 4.0 License.

1081 All (a) are higher than -0.19 , the slope value derived from the theoretical $\delta^{18} \mathrm{O}_{-}$ temperature relationship at equilibrium (Kim et al., 2007). These values indicate that fibers are the

1083 prevailing microstructures of the corals considered.

1084

Fig. 4c displays constant (a) and (b) relationship $b=-32.6 \times a-5.6, R^{2}=0.98, n=4, p<0.01$.

1085

1086

Figure 5 - Clipperton $\delta^{18} \mathrm{O}$ data covering the period 1985-1994 (Linsley et al., 1999, 2000), available on https://www.ncdc.noaa.gov/paleo/study/1846. Three cores are considered 2B, 3C and 4B. Fig. 5a displays $\delta^{18} \mathrm{O}$ profiles characterized by strong annual variability, 2B (orange curve), 3C (green curve), and 4B (blue curve). Fig. 5b shows the three core seasonal $\delta^{18} \mathrm{O}$-monthly temperature calibrations.

$10913 \mathrm{C} \quad \delta^{18} \mathrm{O}_{\text {carbonate }}=-0.39 \times \mathrm{SST}\left({ }^{\circ} \mathrm{C}\right)+5.26$, trend graph derived from 3 temperatures, orange curve

$1092 \quad 3 \mathrm{C} \quad \delta^{18} \mathrm{O}_{\text {carbonate }}=-0.46 \times \operatorname{SST}\left({ }^{\circ} \mathrm{C}\right)+7.4$, trend graph derived from 3 temperatures, green curve

$10934 \mathrm{~B} \quad \delta^{18} \mathrm{O}_{\text {carbonate }}=-0.53 \times \mathrm{SST}\left({ }^{\circ} \mathrm{C}\right)+9.21$, trend graph derived from 3 temperatures, blue curve

1094 The slope values (a) being lower than -0.19 , the slope value derived from the theoretical $\delta^{18} \mathrm{O}-$ temperature relationship at equilibrium (Kim et al., 2007), correspond to coral colonies grown at high temperature showing great amount of $\mathrm{COC}$ compared to fiber amount.

Fig. 5c displays constant (a) and (b) relationship $b=-28.21 \times a+20.27, R^{2}=0.997, n=3, p<0.01$

1099 Figure 6 - 6 coral heads representing 3 Porites species (Porites lutea, Porites murrayensis and Porites australiensis), collected in Taka Bone Rate (Indonesia), have been sampled. Each species, composed by two coral heads, provides four sampling profiles covering 4 years. Each trajectory presents different light incidence. Fig.6a shows all the calibrations. Except one calibration of Porites australiansis, all the other calibrations exhibit intersection close to the temperature and $\delta^{18} \mathrm{O}$ ranges defined for Porites group (Fig. 1d). All the calibrations constants are reported on Fig. 6b. The negative values (a), associated to high linear extension are characteristic features of coral skeleton grown at high temperature richer in $\mathrm{COC}$ than fibres. The correlation coefficient given for all Porites species is high: $\mathrm{b}=-28.34 \times \mathrm{a}-5.59, \mathrm{R}^{2}=0.999, \mathrm{n}=12, \mathrm{p}<0.001$ 
Biogeosciences Discuss., https://doi.org/10.5194/bg-2018-433

Manuscript under review for journal Biogeosciences

Discussion started: 19 October 2018

(c) Author(s) 2018. CC BY 4.0 License.

1109 Figure 7 - Fig. 7a displays Porites seasonal $\delta^{18} \mathrm{O}-$ monthly temperature calibrations of New Caledonia corals (Quinn and Sampson, 2002; Stephans et al., 2004), Clipperton corals (Linsey et al., 1999, 2000), Taka Bone Rate corals (Maier et al., 2004) and annual $\delta^{18} \mathrm{O}$-annual temperature calibration derived from Weber and Woodhead (1972) data series. On Fig. 7b are plotted all the (a) and (b) values corresponding to the calibrations reported on Fig. 7a. The correlation coefficient given for all Porites species is high: $\mathrm{b}=-27.24 \mathrm{x} a-4.92, \mathrm{R}^{2}=0.999, \mathrm{n}=30, \mathrm{p}<0.001$. All dots showing (a) $>-0.19$, the slope value derived from the theoretical $\delta^{18} \mathrm{O}$-temperature relationship at equilibrium (Kim et al., 2007) correspond to New Caledonia coral cores developed at mitigated temperatures, with fibers in greater amounts compared to COC, all other ones showing (a) $<-0.19$ are associated to corals grown at high temperature, with reverse microstructures relative amounts.

Figure 8 - Comparison of $\delta^{18} \mathrm{O}$ measured on coral core collected at Moorea (French Polynesia) (Boiseau et al., 1998) and measured and estimated temperatures. On the left side Fig. 8a, between 1980 and 1990, the seasonal measured data are compared to the instrumental seawater temperature (Boiseau et al., 1998). On the right side Fig. 8b, over the last century, the annual averaged measured data, originated from the same data series than seasonal data, are compared to the temperature estimated in the $\left(1^{\circ}, 1^{\circ}\right)$ grid containing Moorea (Kaplan et al., 1998). The two curves are displayed to obtain the best matching. The isotopic scale of the two isotopic profiles is common to the two profiles, while the measured and the estimated temperature scales cover $7^{\circ} \mathrm{C}$ and $2^{\circ} \mathrm{C}$ respectively. There is a mismatch between the annual and monthly calibrations given on a unique isotopic scale, illustrating the non-linearity between the monthly and annual $\delta^{18} \mathrm{O}$ profiles over the time.

Figure 9 - Comparison of the monthly composite $\delta^{18} \mathrm{O}$-monthly composite temperature calibration 1132 calculated over 1979 to 1989 (Fig. 9a) and the annual $\delta^{18} \mathrm{O}$-annual temperature calibration calculated 1133 over 33 years (from 1989 to 1956) (Fig. 9b) (Boiseau et al., 1998). The averaged temperature 1134 calculated from the composite temperature is $25.88^{\circ} \mathrm{C}$ whereas the averaged temperature from the last 
Biogeosciences Discuss., https://doi.org/10.5194/bg-2018-433

Manuscript under review for journal Biogeosciences

Discussion started: 19 October 2018

(c) Author(s) 2018. CC BY 4.0 License.

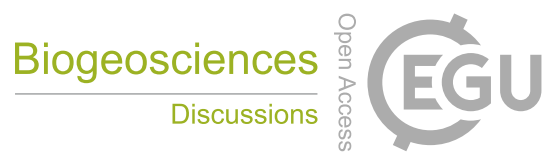

(c) (i)

45

113530 years is $26.7^{\circ} \mathrm{C}$. (a) of the monthly composite $\delta^{18} \mathrm{O}$-monthly composite temperature calibration

1136 shown on Fig. 9a is -0.15 similar with slope obtained from New Caledonia, however, the composite

1137 temperatures may not be really compared with the measurements. Fig. 9b displays the annual $\delta^{18} \mathrm{O}-$

1138 annual temperature calibration with the slope (a) slightly lower than -0.19 the slope value derived

1139 from the theoretical $\delta^{18} \mathrm{O}$-temperature relationship at equilibrium (Kim et al., 2007) in good

1140 agreement with the values reported on Fig. 7b.

1141 
Biogeosciences Discuss., https://doi.org/10.5194/bg-2018-433

Manuscript under review for journal Biogeosciences

Discussion started: 19 October 2018

(c) Author(s) 2018. CC BY 4.0 License.

\begin{tabular}{|c|c|c|c|c|c|c|c|c|}
\hline \multirow[t]{2}{*}{ Genus } & \multirow{2}{*}{ Family } & \multirow{2}{*}{ Suborder } & \multirow{2}{*}{ Group } & \multicolumn{2}{|c|}{$\delta^{18} \mathrm{O}$ and temperature ranges } & \multirow{2}{*}{$\mathrm{R}=$ Specimen $\mathrm{nb} /$ Site $\mathrm{nb}$} & \multirow[t]{2}{*}{ b } & \multirow[t]{2}{*}{$\mathbf{a}$} \\
\hline & & & & SST $^{\circ} \mathrm{C}$ & $\delta^{18} \mathrm{O} \%$ vs VPDB & & & \\
\hline Platygyra & Faviidae & FA & \multirow{9}{*}{ I } & \multirow{9}{*}{24.42} & \multirow{9}{*}{-4.18} & 8.23 & 2.24 & -0.27 \\
\hline Leptoria & Faviidae & FA & & & & 3.36 & 2.37 & -0.27 \\
\hline Goniopora & Poritidae & $\mathrm{FU}$ & & & & 6.46 & 0.99 & -0.21 \\
\hline Goniastrea & Faviidae & FA & & & & 7.00 & 1.72 & -0.24 \\
\hline Echinophyllia & Faviidae & FA & & & & 2.14 & 2.29 & -0.26 \\
\hline Oxypora & Pectiniidae & FA & & & & 1.80 & 1.32 & -0.22 \\
\hline Astreopora & Fungiidae & A & & & & 4.67 & 0.72 & -0.20 \\
\hline Favites & Faviidae & FA & & & & 6.55 & 1.67 & -0.24 \\
\hline Plesiastrea & Faviidae & FA & & & & 6.00 & 1.82 & -0.24 \\
\hline Coeloseris & Agariciidae & $\mathrm{FU}$ & \multirow{8}{*}{ II } & \multirow{8}{*}{26.63} & \multirow{8}{*}{-4.91} & 4.80 & -0.48 & -0.17 \\
\hline Caulastrea & Faviidae & FA & & & & 3.00 & 2.96 & -0.30 \\
\hline Acrhelia & Faviidae & FA & & & & 2.50 & 0.44 & -0.20 \\
\hline Oulophyllia & Faviidae & FA & & & & 2.50 & -1.68 & -0.12 \\
\hline Lobophyllia & Mussidae & FA & & & & 7.07 & 0.92 & -0.22 \\
\hline Symphyllia & Mussidae & FA & & & & 3.75 & 1.09 & -0.22 \\
\hline Favia & Faviidae & FA & & & & 6.56 & 1.53 & -0.24 \\
\hline Acanthastrea & Mussidae & $\mathrm{FA}$ & & & & 2.30 & 2.72 & -0.28 \\
\hline Pavona & Agariciidae & $\overline{\mathrm{FU}}$ & \multirow{7}{*}{ III } & \multirow{7}{*}{25.85} & \multirow{7}{*}{-4.10} & 7.94 & 2.18 & -0.25 \\
\hline Alveopora & Poritidae & $\mathrm{FU}$ & & & & 3.40 & 1.44 & -0.21 \\
\hline Diploastrea & Faviidae & FA & & & & 2.17 & 2.11 & -0.24 \\
\hline Cyphastrea & Faviidae & FA & & & & 3.81 & 1.08 & -0.20 \\
\hline Fungia & Fungiidae & $\mathrm{FU}$ & & & & 13.62 & 2.74 & -0.26 \\
\hline Polyphyllia & Fungiidae & $\mathrm{FU}$ & & & & 2.57 & 1.24 & -0.21 \\
\hline Leptastrea & Fungiidae & $\mathrm{FU}$ & & & & 5.21 & 2.01 & -0.23 \\
\hline Pliesioseris & Thamnastreiidae & $\mathrm{A}$ & \multirow{11}{*}{ IV } & \multirow{11}{*}{25.6} & \multirow{11}{*}{-3.79} & 3.40 & 2.08 & -0.23 \\
\hline Psammocora & Thamnastreiidae & A & & & & 5.87 & 2.03 & -0.23 \\
\hline Parahalomitra & Fungiidae & $\mathrm{FU}$ & & & & 2.56 & 3.99 & -0.31 \\
\hline Coscinarea & Siderastreiidae & $\mathrm{FU}$ & & & & 3.43 & 2.85 & -0.26 \\
\hline Herpolitha & Fungiidae & FU & & & & 2.22 & 5.39 & -0.36 \\
\hline Seriatopora & Pocilloporidae & A & & & & 4.44 & 3.11 & -0.27 \\
\hline Stephanaria & Thamnastreiidae & A & & & & 1.89 & 4.10 & -0.31 \\
\hline Turbinaria & Dendrophyllidae & D & & & & 6.43 & 4.01 & -0.30 \\
\hline Montipora & Acroporidae & A & & & & 11.70 & 3.76 & -0.29 \\
\hline Acropora & Acroporidae & A & & & & 30.93 & 3.43 & -0.28 \\
\hline Stylophora & Pocilloporidae & A & & & & 6.80 & 2.02 & -0.22 \\
\hline Euphyllia & Caryophylliidae & $\mathrm{C}$ & \multirow{9}{*}{ V } & \multirow{9}{*}{28.4} & & 5.11 & 0.60 & -0.20 \\
\hline Merulina & Merulinidae & FA & & & & 3.75 & 0.68 & -0.21 \\
\hline Pectinea & Pectiniidae & FA & & & & 2.80 & -0.58 & -0.16 \\
\hline Galaxea & Oculinidae & FA & & & & 5.07 & 1.98 & -0.25 \\
\hline Hydnophora & Faviidae & FA & & & -5.16 & 3.89 & 2.87 & -0.28 \\
\hline Echinopora & Faviidae & FA & & & & 5.27 & 2.93 & -0.28 \\
\hline Porites & Poritidae & $\mathrm{FU}$ & & & & 16.19 & 3.39 & -0.30 \\
\hline Pocillopora & Acroporidae & A & & & & 9.33 & 2.37 & -0.26 \\
\hline Mycedium & Pectiniidae & FA & & & & 2.00 & 3.87 & -0.32 \\
\hline
\end{tabular}

Table 1 - Groups of coral genera from WW72, identified as showing $\delta^{18} \mathrm{O}$-temperature calibration constants linearly linked with correlation coefficient $\mathrm{R}^{2} \geq 0.99$ (Fig. 3). They have been first highlighted by calibrations forming bundle characterized by intersections defining $\delta^{18} \mathrm{O}$ and temperature ranges (Fig. 1d). 
Biogeosciences Discuss., https://doi.org/10.5194/bg-2018-433

Manuscript under review for journal Biogeosciences

Discussion started: 19 October 2018

(c) Author(s) 2018. CC BY 4.0 License.

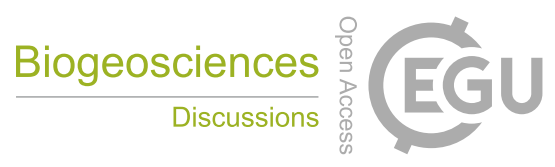

(c) (i)

47

1150

1151

Table 2 - Values of constant of $\delta^{18} \mathrm{O}$-temperature calibrations from WW72, and from New

1157 Caledonia (Stephans et al., 2004), Clipperon (Linsley et al., 1999) and Indonesia (Maier et al., 2004).

1158 
Biogeosciences Discuss., https://doi.org/10.5194/bg-2018-433

Manuscript under review for journal Biogeosciences

Discussion started: 19 October 2018

(c) Author(s) 2018. CC BY 4.0 License.

(a)
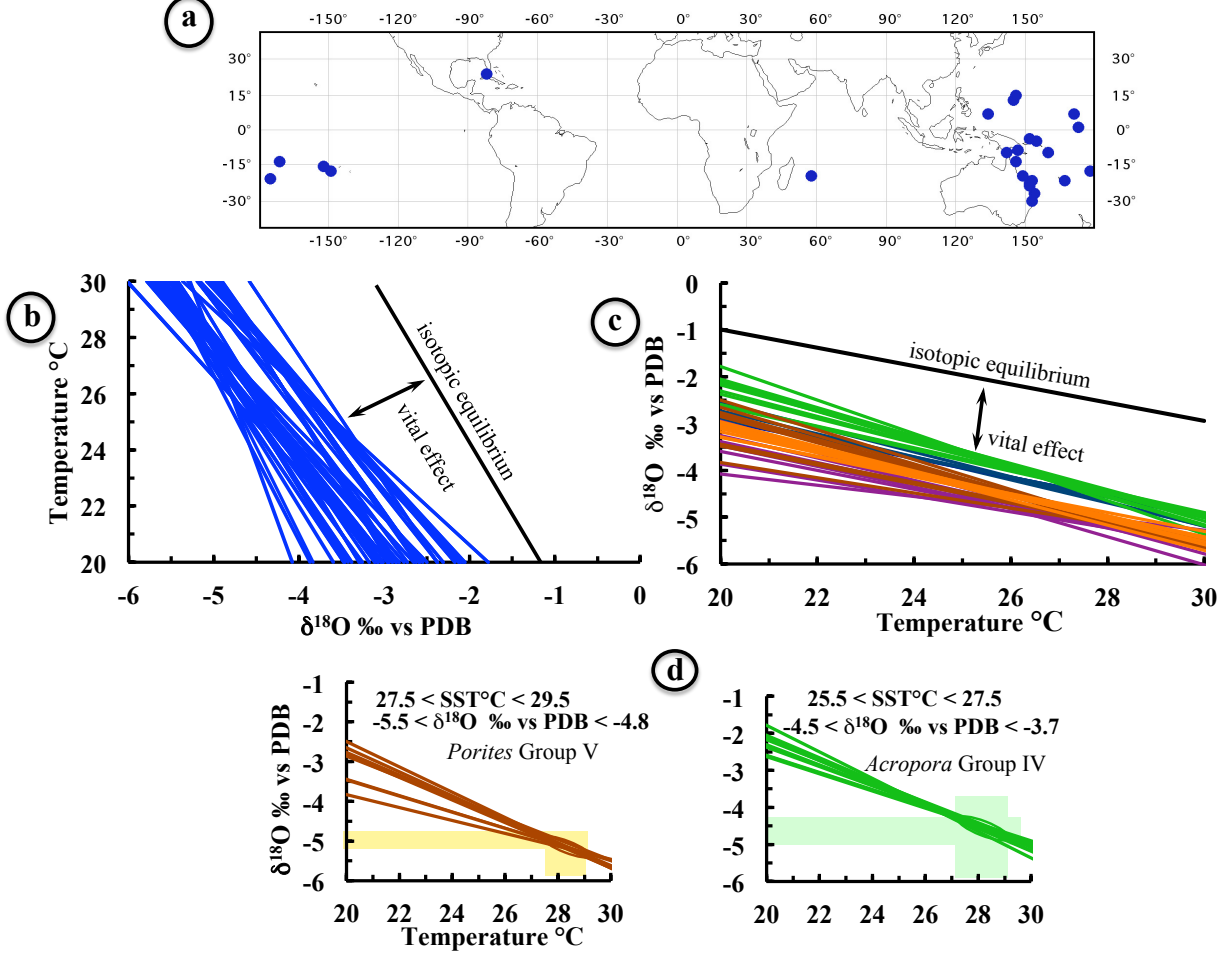

(d)

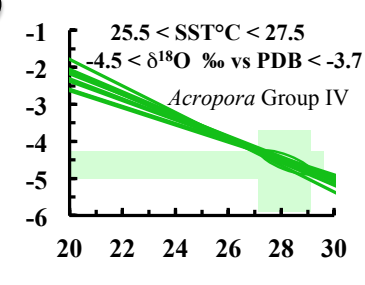

Figure 1 - Figures of the revisited Weber and Woodhead (1972) data series. Fig. 1a is the location of all the islands considered by the authors determining temperatures. Fig. 1b displays calibrations annual temperature-annual $\delta^{18} \mathrm{O}$, plotted by considering annual temperature as the unknown parameters. Fig. 1c displays annual $\delta^{18} \mathrm{O}$-annual temperature calibrations plotted with annual coral $\delta^{18} \mathrm{O}$ as the unknown parameter, annual temperature being the robust parameter. Fig. 1d displays bundles of annual $\delta^{18} \mathrm{O}$-annual temperature calibrations as we identify them from Fig. 1c, for the groups including Porites and Acropora. From Fig. 1d, it is possible to generate annual temperature and annual $\delta^{18} \mathrm{O}$ ranges corresponding to the intersection of the calibrations. This feature is made possible by the homogenous light influence on calibrations. 
Biogeosciences Discuss., https://doi.org/10.5194/bg-2018-433

Manuscript under review for journal Biogeosciences

Discussion started: 19 October 2018

(c) Author(s) 2018. CC BY 4.0 License.

Discussions

(c) (i)

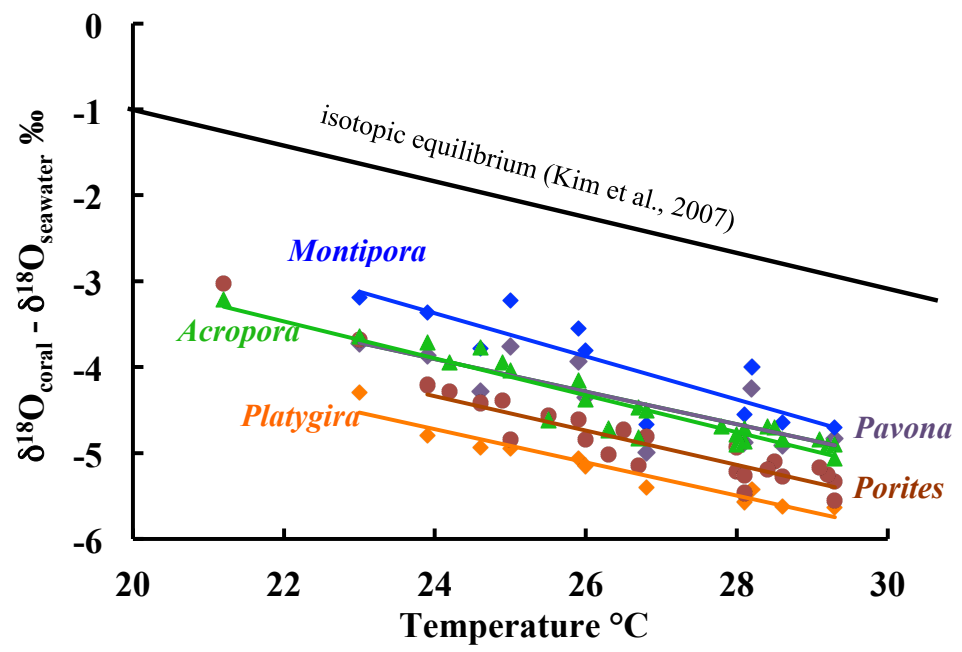

1174

1175

1176

1177

1178

1179

1180

1181

1182

1183

1184

1185

1186

1187

Figure 2 - Annual $\left(\delta^{18} \mathrm{O}_{\text {coral }}-\delta^{18} \mathrm{O}_{\text {seawater }}\right)$-annual temperature calibrations. Weber and Woohead (1972) data series provided coral data. $\delta^{18} \mathrm{O}_{\text {seawater }}$ are introduced in the annual $\delta^{18} \mathrm{O}$-annual temperature calibrations according to Juillet-Leclerc and Schmidt (2001) method. Some genera are not present in all the sites, in turn at all temperatures and only corresponding $\delta^{18} \mathrm{O}_{\text {seawater }}$ are introduced.

Acropora $\quad \delta^{18} \mathrm{O}_{\text {carbonate }}-\delta^{18} \mathrm{O}_{\text {seawater }}=-0.21 \times \mathrm{SST}\left({ }^{\circ} \mathrm{C}\right)+1.26, \mathrm{R}^{2}=0.87, \mathrm{n}=24, \mathrm{p}<0.001$

Porites $\quad \delta^{18} \mathrm{O}_{\text {carbonate }}-\delta^{18} \mathrm{O}_{\text {seawater }}=-0.20 \times \operatorname{SST}\left({ }^{\circ} \mathrm{C}\right)+0.45, \mathrm{R}^{2}=0.83, \mathrm{n}=22, \mathrm{p}<0.001$

Montipora $\quad \delta^{18} \mathrm{O}_{\text {carbonate }}-\delta^{18} \mathrm{O}_{\text {seawater }}=-0.19 \times \operatorname{SST}\left({ }^{\circ} \mathrm{C}\right)+0.64, \mathrm{R}^{2}=0.64, \mathrm{n}=12, \mathrm{p}<0.05$

Platygira $\quad \delta^{18} \mathrm{O}_{\text {carbonate }}-\delta^{18} \mathrm{O}_{\text {seawater }}=-0.19 \times \operatorname{SST}\left({ }^{\circ} \mathrm{C}\right)-0.08, \mathrm{R}^{2}=0.93, \mathrm{n}=11, \mathrm{p}<0.001$

Pavona $\quad \delta^{18} \mathrm{O}_{\text {carbonate }}-\delta^{18} \mathrm{O}_{\text {seawater }}=-0.17 \times \operatorname{SST}\left({ }^{\circ} \mathrm{C}\right)-0.47, \mathrm{R}^{2}=0.87, \mathrm{n}=8, \mathrm{p}<0.01$

Discrepancies between the different genera calibrations are related to microstructure distribution characterizing each morphology. 
Biogeosciences Discuss., https://doi.org/10.5194/bg-2018-433

Manuscript under review for journal Biogeosciences

Discussion started: 19 October 2018

(c) Author(s) 2018. CC BY 4.0 License.

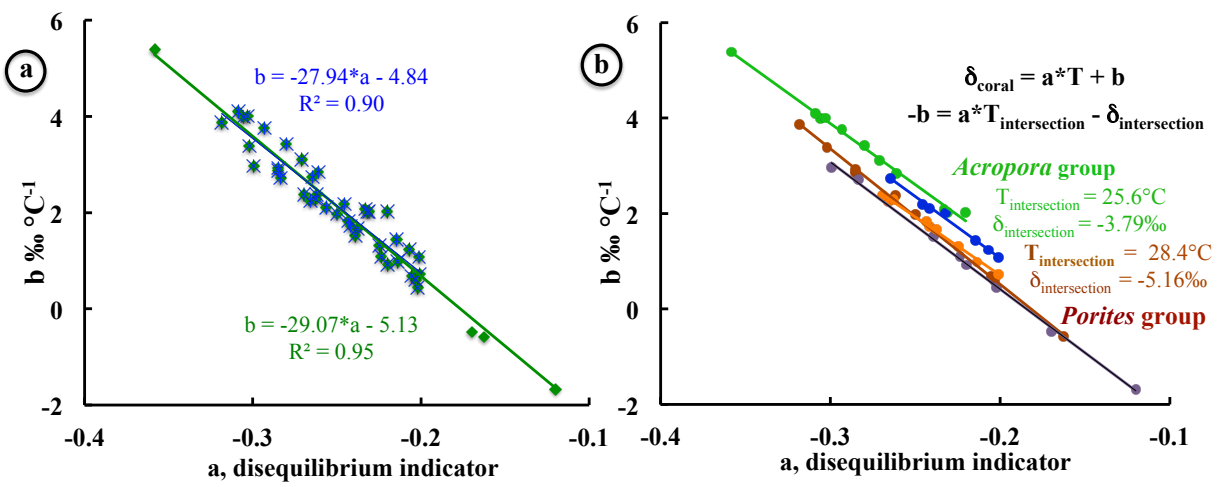

Figure 3 - Linear relationship between (b) and (a), constants of the annual $\delta^{18} \mathrm{O}$-annual temperature calibrations, $\delta^{18} \mathrm{O}_{\text {carbonate }}=\mathrm{a} \times \mathrm{SST}\left({ }^{\circ} \mathrm{C}\right)+\mathrm{b}$. Weber and Woohead (1972) data series provided coral data. Fig. 3a displays constants values from the 44 coral genera of Table 1. (a) is considered as the disequilibrium indicator compared to -0.19 , the slope value derived from the theoretical $\delta^{18} \mathrm{O}$ temperature relationship at equilibrium (Kim et al., 2007). The relationship $b=-29.07 \times \mathrm{a}-5.13, \mathrm{R}^{2}=$ $0.95, \mathrm{n}=44, \mathrm{p}<0.001$ (the green line) takes into account all the data (dark green diamonds), whereas $\mathrm{b}$ $=-27.94 \times \mathrm{a}-4.84, \mathrm{R}^{2}=0.90, \mathrm{n}=40, \mathrm{p}<0.001$ (the blue line) is assessed without the 4 extreme data (the remaining data are the blue crosses). On Fig. 3b, the dots are similar to the dots displayed on Fig. 3a, however, color of the dots corresponds to the color of the calibration bundles of Fig. 1c.

Group I $\quad \mathrm{b}=-24.43 \times \mathrm{a}-4.18, \mathrm{R}^{2}=0.99, \mathrm{n}=9, \mathrm{p}<0.001$ (the orange line)

Group II $\quad \mathrm{b}=-26.63 \times \mathrm{a}-4.91, \mathrm{R}^{2}=0.99, \mathrm{n}=8, \mathrm{p}<0.001$ (the violin line)

Group III $\quad \mathrm{b}=-25.85 \times \mathrm{a}-4.10, \mathrm{R}^{2}=0.99, \mathrm{n}=7, \mathrm{p}<0.001$ (the blue line)

Acropora Group IV $\quad \mathrm{b}=-25.60 \times \mathrm{a}-3.79, \mathrm{R}^{2}=0.99, \mathrm{n}=10, \mathrm{p}<0.001$ (the green line)

Porites Group V $\quad \mathrm{b}=-28.40 \times \mathrm{a}-5.16, \mathrm{R}^{2}=0.999, \mathrm{n}=9, \mathrm{p}<0.001$ (the brown line)

$\mathrm{T}_{\text {intersection }}$ and $\delta_{\text {intersection }}$ are only given for Acropora and Porites groups.

Correlation coefficient of all the linear relationships are very high. All genera included in each group share identical microstructure distribution due to common feature of morphology. 
Biogeosciences Discuss., https://doi.org/10.5194/bg-2018-433

Manuscript under review for journal Biogeosciences

Discussion started: 19 October 2018

(c) Author(s) 2018. CC BY 4.0 License.

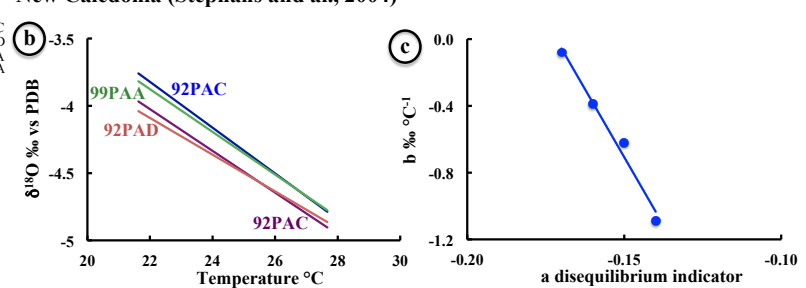

Figure 4 -Graphs derived from Stephans et al. (2004) data, available on NOAA (National Climatic Data Center site) (https://www.ncdc.noaa.gov/paleo/study/1877). On Fig. 4a are reported seasonal isotopic profiles from 1967 to 1993 time period for 92PAC coral core (blue curve), 92PAD coral core (pink curve), 99PAA coral core (green curve) and 92PAA coral core (violin curve). All the cores have been harvested at Fort Amédée lighthouse proximity. Seasonal isotopic profiles are strongly impacted by seasonality with different light influence. Fig. $4 \mathbf{b}$ displays seasonal $\delta^{18} \mathrm{O}$-seasonal temperature (GISS SST) calibrations for the coral cores studied.

$$
\begin{array}{ll}
\text { 92PAC } & \delta^{18} \mathrm{O}_{\text {carbonate }}=-0.17 \times \operatorname{SST}\left({ }^{\circ} \mathrm{C}\right)-0.08, \mathrm{R}^{2}=0.77, \mathrm{n}=296, \mathrm{p}<0.001, \text { blue curve } \\
\text { 99PAA } & \delta^{18} \mathrm{O}_{\text {carbonate }}=-0.16 \times \operatorname{SST}\left({ }^{\circ} \mathrm{C}\right)-0.39, \mathrm{R}^{2}=0.67, \mathrm{n}=296, \mathrm{p}<0.001, \text { green curve } \\
\text { 92PAC } & \delta^{18} \mathrm{O}_{\text {carbonate }}=-0.15 \times \mathrm{SST}\left({ }^{\circ} \mathrm{C}\right)-0.62, \mathrm{R}^{2}=0.62, \mathrm{n}=296, \mathrm{p}<0.001, \text { violin curve } \\
\text { 92PAD } & \delta^{18} \mathrm{O}_{\text {carbonate }}=-0.14 \times \operatorname{SST}\left({ }^{\circ} \mathrm{C}\right)-1.09, \mathrm{R}^{2}=0.59, \mathrm{n}=296, \mathrm{p}<0.001, \text { pink curve }
\end{array}
$$
All (a) are higher than -0.19 , the slope value derived from the theoretical $\delta^{18} \mathrm{O}$ temperature relationship at equilibrium (Kim et al., 2007). These values indicate that fibers are the prevailing microstructures of the corals considered.

Fig. 4c displays constant (a) and (b) relationship $b=-32.6 \times a-5.6, \mathrm{R}^{2}=0.98, \mathrm{n}=4, \mathrm{p}<0.01$. 
Biogeosciences Discuss., https://doi.org/10.5194/bg-2018-433

Manuscript under review for journal Biogeosciences

Discussion started: 19 October 2018

(c) Author(s) 2018. CC BY 4.0 License.

1227

1228

1229

1230

1231

1232

1233

1234

1235

1236

1237

1238

1239

1240

1241

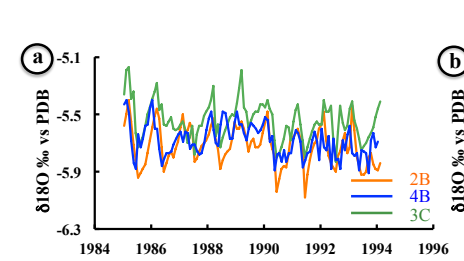

Clipperton (Linsley et al., 1999)
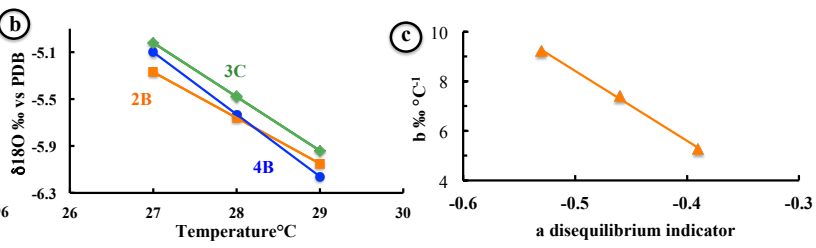

Figure 5 - Clipperton $\delta^{18} \mathrm{O}$ data covering 1985-1994 period (Linsley et al., 1999, 2000), available on https://www.ncdc.noaa.gov/paleo/study/1846. Three cores are considered 2B, 3C and 4B. Fig. 5a displays $\delta^{18} \mathrm{O}$ profiles characterized by strong annual variability, 2B (orange curve), 3C (green curve), and 4B (blue curve). Fig. 5b shows the three core seasonal $\delta^{18} \mathrm{O}-$ monthly temperature calibrations. $3 \mathrm{C} \delta \delta^{18} \mathrm{O}_{\text {carbonate }}=-0.39 \times \mathrm{SST}\left({ }^{\circ} \mathrm{C}\right)+5.26$, trend graph derived from 3 temperatures, orange curve $3 \mathrm{C} \delta{ }^{18} \mathrm{O}_{\text {carbonate }}=-0.46 \times \mathrm{SST}\left({ }^{\circ} \mathrm{C}\right)+7.4$, trend graph derived from 3 temperatures, green curve 4B $\delta^{18} \mathrm{O}_{\text {carbonate }}=-0.53 \times \mathrm{SST}\left({ }^{\circ} \mathrm{C}\right)+9.21$, trend graph derived from 3 temperatures, blue curve The slope values (a) being lower than -0.19 , the slope value derived from the theoretical $\delta^{18} \mathrm{O}$ temperature relationship at equilibrium (Kim et al., 2007), correspond to coral colonies grown at high temperature showing great amount of COC compared to fibre amount.

Fig. 5c displays constant (a) and (b) relationship $b=-28.21 \times a+20.27, R^{2}=0.997, n=3, p<0.01$ 
Biogeosciences Discuss., https://doi.org/10.5194/bg-2018-433

Manuscript under review for journal Biogeosciences

Discussion started: 19 October 2018

(c) Author(s) 2018. CC BY 4.0 License.

Taka Bone Rate (Indonesia) (Maier et al., 2004)
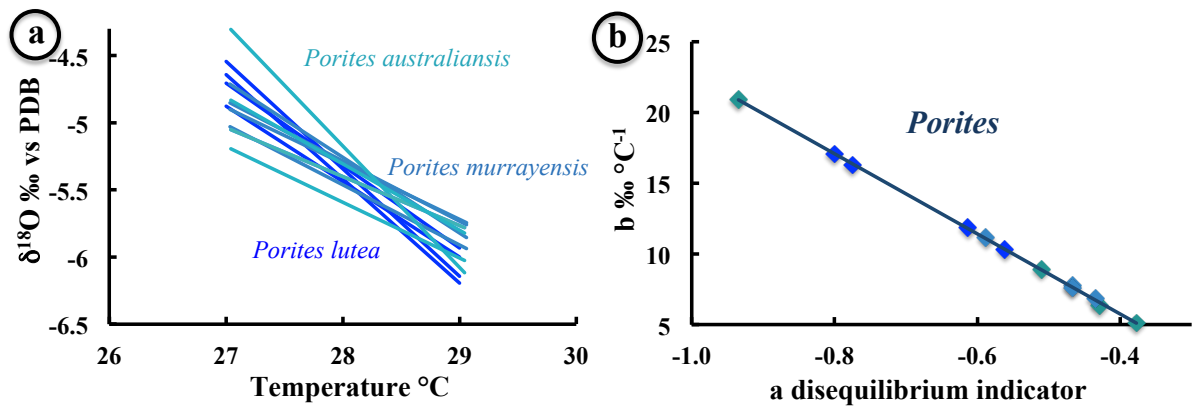

1243

1244

1245

1246

1247

1248

1249

1250

1251

1252

1253

1254

Figure 6 - 6 coral heads representing 3 Porites species (Porites lutea, Porites murrayensis and Porites australiensis), collected in Taka Bone Rate (Indonesia), have been sampled. Each species, composed by two coral heads, provides four sampling profiles covering 4 years. Each trajectory presents different light incidence. Fig.6a shows all the calibrations. Except one calibration of Porites australiansis, all the other calibrations exhibit intersection close to the temperature and $\delta^{18} \mathrm{O}$ ranges defined for Porites group (Fig. 1d). All the calibrations constants are reported on Fig. 6b. The negative values (a), associated to high linear extension are characteristic features of coral skeleton grown at high temperature richer in COC than fibres. The correlation coefficient given for all Porites species is high: $\mathrm{b}=-28.34 \times \mathrm{a}-5.59, \mathrm{R}^{2}=0.999, \mathrm{n}=12, \mathrm{p}<0.001$ 
Biogeosciences Discuss., https://doi.org/10.5194/bg-2018-433

Manuscript under review for journal Biogeosciences

Discussion started: 19 October 2018

(c) Author(s) 2018. CC BY 4.0 License.
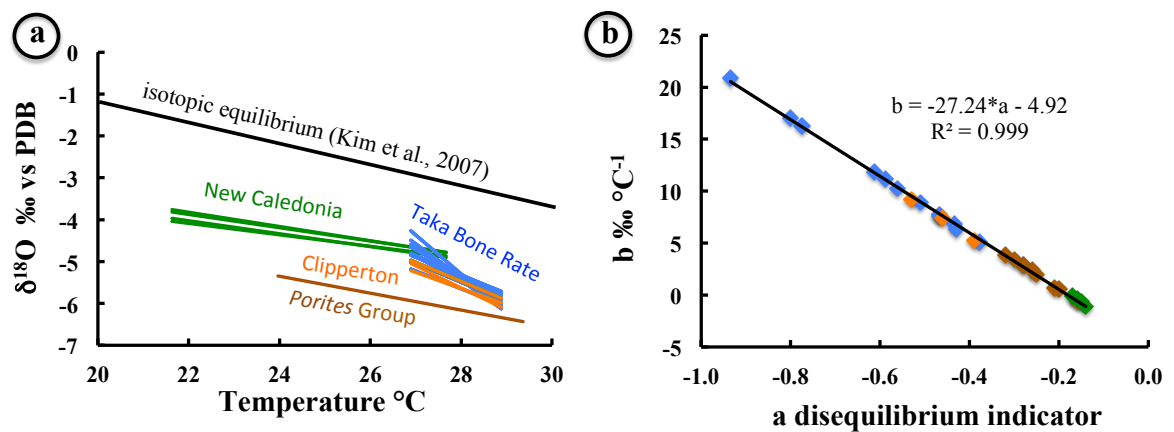

1259

Figure 7 - Fig. 7a displays Porites seasonal $\delta^{18} \mathrm{O}$-monthly temperature calibrations of New

Caledonia corals (Quinn and Sampson, 2002; Stephans et al., 2004), Clipperton corals (Linsey et al.,

1999, 2000), Taka Bone Rate corals (Maier et al., 2004) and annual $\delta^{18} \mathrm{O}$-annual temperature

1261

calibration derived from Weber and Woodhead (1972) data series. On Fig. 7b are plotted all the (a)

1262 and (b) values corresponding to the calibrations reported on Fig. 7a. The correlation coefficient given for all Porites species is high: $\mathrm{b}=-27.24 \mathrm{x}$ a $-4.92, \mathrm{R}^{2}=0.999, \mathrm{n}=30, \mathrm{p}<0.001$. All dots showing (a)

$1264>-0.19$, the slope value derived from the theoretical $\delta^{18} \mathrm{O}$-temperature relationship at equilibrium

(Kim et al., 2007) correspond to New Caledonia coral cores developed at mitigated temperatures, with 
Biogeosciences Discuss., https://doi.org/10.5194/bg-2018-433

Manuscript under review for journal Biogeosciences

Discussion started: 19 October 2018

(c) Author(s) 2018. CC BY 4.0 License.

1269

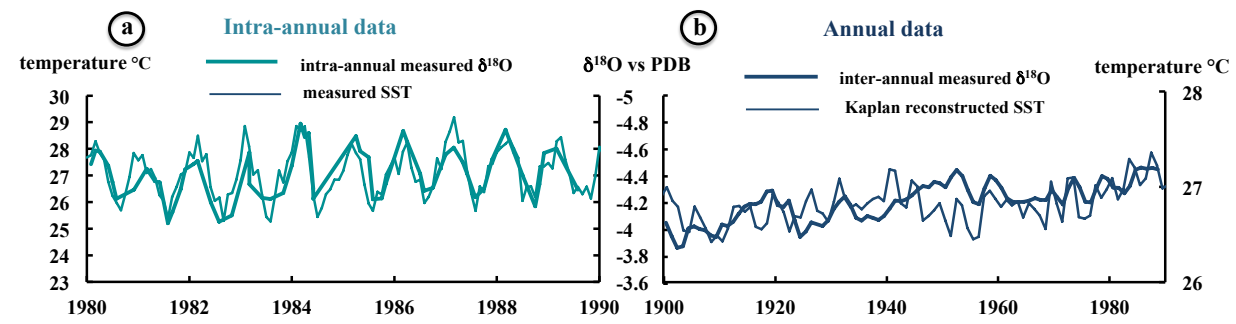

1270

1271

1272

1273

1274

1275

1276

1277

1278

1279

1280

1281

1282

Figure 8 - Comparison of $\delta^{18} \mathrm{O}$ measured on coral core collected at Moorea (French Polynesia) (Boiseau et al., 1998) and measured and estimated temperatures. On left hand Fig. 8a, between 1980 and 1990, seasonal measured data are compared to instrumental seawater temperature (Boiseau et al., 1998). On right hand Fig. 8b, over the last century, annual averaged measured data, originated from the same data series than seasonal data, are compared to estimated temperature in the $\left(1^{\circ}, 1^{\circ}\right)$ grid containing Moorea (Kaplan et al., 1998). The two curves are displayed to obtain the best matching. Isotopic scale of the two isotopic profiles is common to the two profiles, while measured and estimated temperature scales cover $7{ }^{\circ} \mathrm{C}$ and $2{ }^{\circ} \mathrm{C}$ respectively. There is a mismatch between annual and monthly calibrations given on a unique isotopic scale, illustrating the non-linearity between monthly and annual $\delta^{18} \mathrm{O}$ profiles over the time. 
Biogeosciences Discuss., https://doi.org/10.5194/bg-2018-433

Manuscript under review for journal Biogeosciences

Discussion started: 19 October 2018

(c) Author(s) 2018. CC BY 4.0 License.

Figure 9 - Comparison of monthly composite $\delta^{18} \mathrm{O}$-monthly composite temperature calibration calculated over 1979 to 1989 (Fig. 9a) and annual $\delta^{18}$ O-annual temperature calibration calculated over 33 years (from 1989 to 1956) (Fig. 9b) (Boiseau et al., 1998). Averaged temperature calculated from composite temperature is $25.88^{\circ} \mathrm{C}$ whereas averaged temperature from the last 30 years is $26.7^{\circ} \mathrm{C}$. (a) of the monthly composite $\delta^{18} \mathrm{O}$-monthly composite temperature calibration shown on Fig. 9a is -0.15 similar with slope obtained from New Caledonia, however, composite temperatures may not be really compared with measurements. Fig. 9b displays annual $\delta^{18} \mathrm{O}$-annual temperature calibration with slope (a) slightly lower than -0.19 the slope value derived from the theoretical $\delta^{18} \mathrm{O}$-temperature relationship at equilibrium (Kim et al., 2007) in good agreement with values reported on Fig. 7b. 